\title{
A Transferable Force Field for Predicting Adsorption and Diffusion of Small Molecules in Alkali Metal Exchanged Zeolites with Coupled Cluster Accuracy: Supporting Information
}

\author{
Salah Eddine Boulfelfel ${ }^{1}$, John M. Findley ${ }^{1}$, Hanjun Fang ${ }^{1}$, Alan S. S. Daou ${ }^{1}$, Peter I. \\ Ravikovitch $^{2 \dagger^{*}}$, and David S. Sholl ${ }^{1 * *}$ \\ ${ }^{1}$ School of Chemical and Biomolecular Engineering, Georgia Institute of Technology, \\ Atlanta, Georgia 30332-0100, United States \\ ${ }^{2}$ Corporate Strategic Research, ExxonMobil Research and Engineering, \\ 1545 Route 22 East, Annandale, New Jersey 08801, United States \\ $\dagger+1-908-730-2280$, peter.ravikovitch@exxonmobil.com \\ $\$+1-404-894-2822$, david.sholl@,chbe.gatech.edu
}


Table of Contents

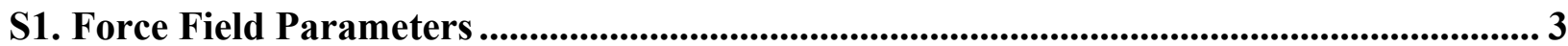

S2. Fitting and Additional Validation of Cation-Framework Interactions ............................ 6

S3. Additional Adsorption Validation and Aluminum Distribution Effects ........................... 10

S4. Additional Diffusion Validation .............................................................................................. 22

S5. Sample LAMMPS Input File................................................................................ 29

References ......................................................................................................................................... 31 


\section{S1. Force Field Parameters}

Table S1. The force field parameters obtained for cation-framework interactions. The vdW interactions are described by a Buckingham potential with parameters A, B and C. Coulombic interactions use DDEC6 point charges. Oxygen atoms connected to aluminum are considered to be Oa when the zeolite is fully exchanged with $\mathrm{Na}, \mathrm{K}, \mathrm{Rb}$, or $\mathrm{Cs}$, and OLi when the zeolite is fully exchanged with Li.

\begin{tabular}{llllll}
\hline Cross-Species & $\mathrm{A}\left(10^{4} \mathrm{~K}\right)$ & $\mathrm{B}\left(\AA^{-1}\right)$ & $\mathrm{C}\left(10^{3} \mathrm{~K} \times \AA^{6}\right)$ & Species & Charge (e) \\
\hline $\mathrm{Li}-\mathrm{O}_{\mathrm{z}}$ & 3516 & 4.723 & 135 & $\mathrm{Si}$ & 1.8708 \\
$\mathrm{Na}-\mathrm{O}_{\mathrm{z}}$ & 5581 & 3.985 & 917 & $\mathrm{Al}$ & 1.7906 \\
$\mathrm{~K}-\mathrm{O}_{\mathrm{z}}$ & 6967 & 3.475 & 2617 & $\mathrm{O}$ & -0.9354 \\
$\mathrm{Rb}-\mathrm{O}_{\mathrm{z}}$ & 4150 & 3.228 & 2221 & $\mathrm{Oa}$ & -1.1427 \\
$\mathrm{Cs}-\mathrm{O}_{\mathrm{z}}$ & 4420 & 2.844 & 6499 & $\mathrm{OLi}$ & -1.1288 \\
& & & & $\mathrm{Li}$ & 0.8538 \\
& & & & $\mathrm{Na}, \mathrm{K}, \mathrm{Rb}, \mathrm{Cs}$ & 0.9094 \\
\hline
\end{tabular}

Table S2. The CCFF Lennard-Jones parameters for $\mathrm{CO}_{2}$ are shown. The Lennard-Jones parameters for interactions with $\mathrm{Si}$ and $\mathrm{Oz}$ were fit in Findley et al. ${ }^{1}$.

\begin{tabular}{|c|c|c|c|c|}
\hline Cross-Species & $\varepsilon(\mathrm{K})$ & $\sigma(\AA)$ & Species & Charge (e) \\
\hline $\mathrm{O} \_\mathrm{co} 2-\mathrm{Oz}(\mathrm{Oa})$ & 23.5 & 3.063 & O_co2 & -0.3256 \\
\hline $\mathrm{O} \_\mathrm{c}$ - $2-\mathrm{Si}$ & 39.1 & 3.490 & $\mathrm{C}_{-}^{-} \mathrm{co} 2$ & 0.6512 \\
\hline $\mathrm{O} \_$co $2-\mathrm{Al}$ & 39.1 & 3.054 & & \\
\hline $\mathrm{O}_{-}^{-} \mathrm{co} 2-\mathrm{Li}$ & 240.0 & 2.139 & & \\
\hline $\mathrm{O} \_\mathrm{co} 2-\mathrm{Na}$ & 84.6 & 2.547 & & \\
\hline $\mathrm{O} \_$co $2-\mathrm{K}$ & 139 & 2.881 & & \\
\hline $\mathrm{O} \_\operatorname{co} 2-\mathrm{Rb}$ & 79.2 & 3.188 & & \\
\hline $\mathrm{O} \_\mathrm{co} 2-\mathrm{Cs}$ & 54.2 & 3.457 & & \\
\hline $\mathrm{C}_{-}^{-} \mathrm{co} 2-\mathrm{Oz}(\mathrm{Oa})$ & 29.2 & 3.189 & & \\
\hline $\mathrm{C}_{-}^{-} \mathrm{co} 2-\mathrm{Si}$ & 50.0 & 3.616 & & \\
\hline $\mathrm{C}_{-}^{-} \mathrm{co} 2-\mathrm{Al}$ & 49.8 & 3.167 & & \\
\hline $\mathrm{C}_{-}^{-} \mathrm{co} 2-\mathrm{Li}$ & 281.8 & 2.247 & & \\
\hline $\mathrm{C}_{-}^{-} \mathrm{co} 2-\mathrm{Na}$ & 103.2 & 2.659 & & \\
\hline $\mathrm{C}_{-}^{-} \mathrm{co} 2-\mathrm{K}$ & 174.1 & 2.993 & & \\
\hline $\mathrm{C}_{-} \mathrm{co} 2-\mathrm{Rb}$ & 100.7 & 3.306 & & \\
\hline $\mathrm{C} \_\operatorname{co} 2-\mathrm{Cs}$ & 69.7 & 3.578 & & \\
\hline
\end{tabular}


Table S3. The fitted Lennard-Jones parameters for $\mathrm{N}_{2}$ are shown. The Lennard-Jones parameters for interactions with $\mathrm{Si}$ and $\mathrm{Oz}$ were fit in Findley et al. ${ }^{1}$.

\begin{tabular}{lllll}
\hline Cross-Species & $\varepsilon(\mathrm{K})$ & $\sigma(\AA)$ & Species & Charge (e) \\
\hline N_n2 - Oz (Oa) & 25.8 & 3.213 & N_n2 & -0.40484 \\
N_n2 - Si & 43.5 & 3.652 & N_com & 0.80968 \\
N_n2 - A1 & 55.4 & 3.067 & & \\
N_n2 - Li & 601.9 & 2.093 & & \\
N_n2 - Na & 117.2 & 2.567 & & \\
N_n2 - K & 153.2 & 3.068 & & \\
N_n2 - Rb & 157.7 & 3.221 & & \\
N_n2-Cs & 137.4 & 3.410 & & \\
\hline
\end{tabular}

Table S4. The fitted Lennard-Jones parameters for $\mathrm{O}_{2}$ are shown. The Lennard-Jones parameters for interactions with $\mathrm{Si}$ and $\mathrm{Oz}$ were fit in Findley et al. ${ }^{1}$.

\begin{tabular}{lllll}
\hline Cross-Species & $\varepsilon(\mathrm{K})$ & $\sigma(\AA)$ & Species & Charge (e) \\
\hline O_o2 - Oz (Oa) & 32.6 & 3.506 & O_o2 & -0.112 \\
O_o2 - Al & 59.2 & 3.330 & O_com & 0.224 \\
O_o2 - Li & 711.3 & 1.906 & & \\
O_o2 - Na & 317.2 & 2.308 & & \\
O_o2 - K & 215.8 & 2.789 & & \\
O_o2 - Rb & 31.7 & 3.263 & & \\
O_o2 - Cs & 167.1 & 3.175 & & \\
\hline
\end{tabular}

Table S5. The fitted Lennard-Jones parameters for $\mathrm{CH}_{4}$ are shown. The Lennard-Jones parameters for interactions with $\mathrm{Si}$ and $\mathrm{Oz}$ were fit as a part of this work.

\begin{tabular}{|c|c|c|c|c|}
\hline Cross-Species & $\varepsilon(\mathrm{K})$ & $\sigma(\AA)$ & Species & Charge (e) \\
\hline C_ch4-Oz (Oa) & 20.6 & 3.378 & C_ch4 & -0.240 \\
\hline C_ch4 - Si & 35.1 & 3.830 & H_ch4 & 0.060 \\
\hline $\mathrm{C}^{-} \operatorname{ch} 4-\mathrm{Al}$ & 76.4 & 3.252 & & \\
\hline C_ch4-Li & 366.0 & 2.029 & & \\
\hline C_ch4 $-\mathrm{Na}$ & 158.3 & 2.731 & & \\
\hline C_ch4-K & 72.4 & 3.277 & & \\
\hline $\mathrm{C}_{-}^{-} \mathrm{ch} 4-\mathrm{Rb}$ & 89.3 & 3.419 & & \\
\hline C_ch4-Cs & 111.5 & 3.541 & & \\
\hline $\mathrm{H}_{-}^{-} \mathrm{ch} 4-\mathrm{Oz}(\mathrm{Oa})$ & 16.7 & 2.833 & & \\
\hline H_ch4 - Si & 25.0 & 3.285 & & \\
\hline H_ch4 - Al & 55.7 & 2.777 & & \\
\hline H_ch4-Li & 389.2 & 1.628 & & \\
\hline $\mathrm{H} \_\mathrm{ch} 4-\mathrm{Na}$ & 140.7 & 2.256 & & \\
\hline H_ch4-K & 55.7 & 2.774 & & \\
\hline H_ch4 - Rb & 65.3 & 2.918 & & \\
\hline H_ch4-Cs & 77.2 & 3.050 & & \\
\hline
\end{tabular}



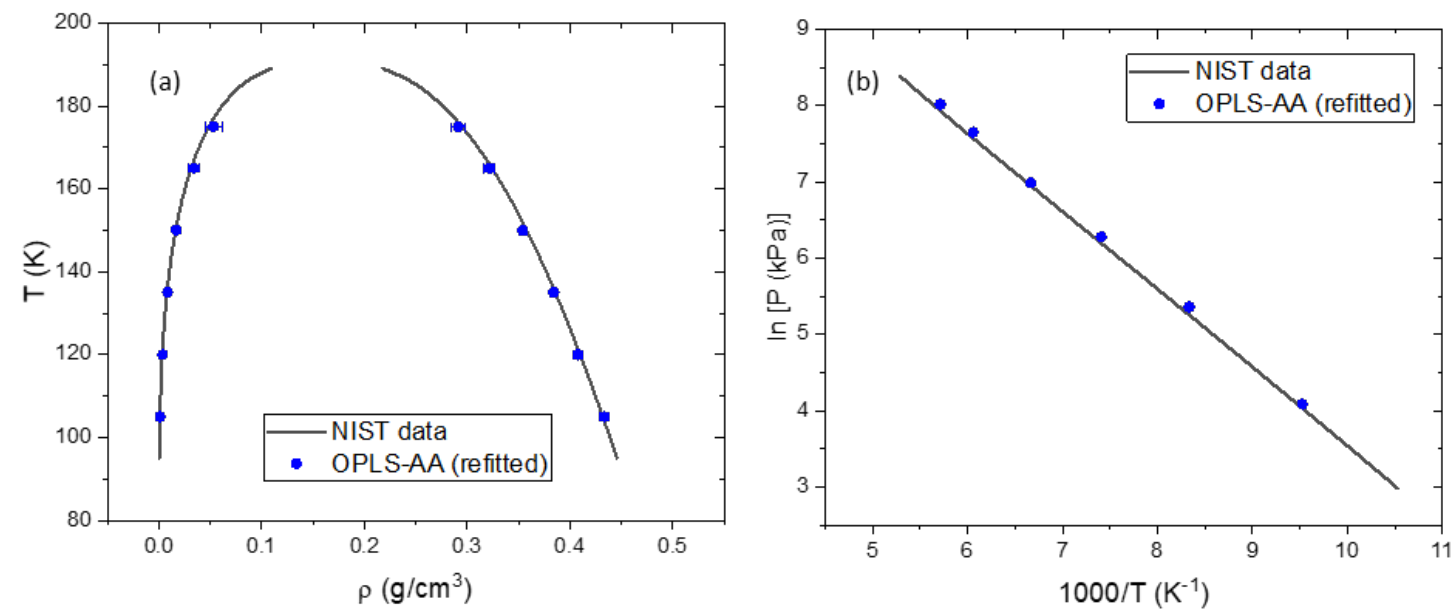

Figure S1. Vapor-liquid coexistence curves for $\mathrm{CH}_{4}$ were simulated with the refitted OPLS-AA model and compared to experimental data from NIST $^{2}$. Vapor and liquid density vs temperature are shown in (a) and saturation vapor pressure is shown in (b). Simulations were performed using Gibbs ensemble MC using RASPA.

Table S6. The Lennard-Jones parameters for adsorbate-adsorbate interactions are shown. $\mathrm{CO}_{2}$ $\mathrm{CO}_{2}$ interactions are described by the EPM- $2^{3}$ model, $\mathrm{N}_{2}-\mathrm{N}_{2}$ interactions are described by the 2LJ3CB.MSKM ${ }^{4,5}$ potential. $\mathrm{O}_{2}-\mathrm{O}_{2}$ interactions are described by the TraPPE ${ }^{6}$ model. $\mathrm{CH}_{4}-\mathrm{CH}_{4}$ interactions are described by the OPLS-AA ${ }^{7}$ model.

\begin{tabular}{lll}
\hline Species & $\varepsilon(\mathrm{K})$ & $\sigma(\AA)$ \\
\hline C_co2 & 28.129 & 2.757 \\
O_co2 & 80.507 & 3.033 \\
N_n2 & 36.4 & 3.32 \\
O_o2 & 49.0 & 3.02 \\
C_ch4 & 58.0 & 3.825 \\
H_ch4 & 7.55 & 2.400 \\
\hline
\end{tabular}




\section{S2. Fitting and Additional Validation of Cation-Framework Interactions}

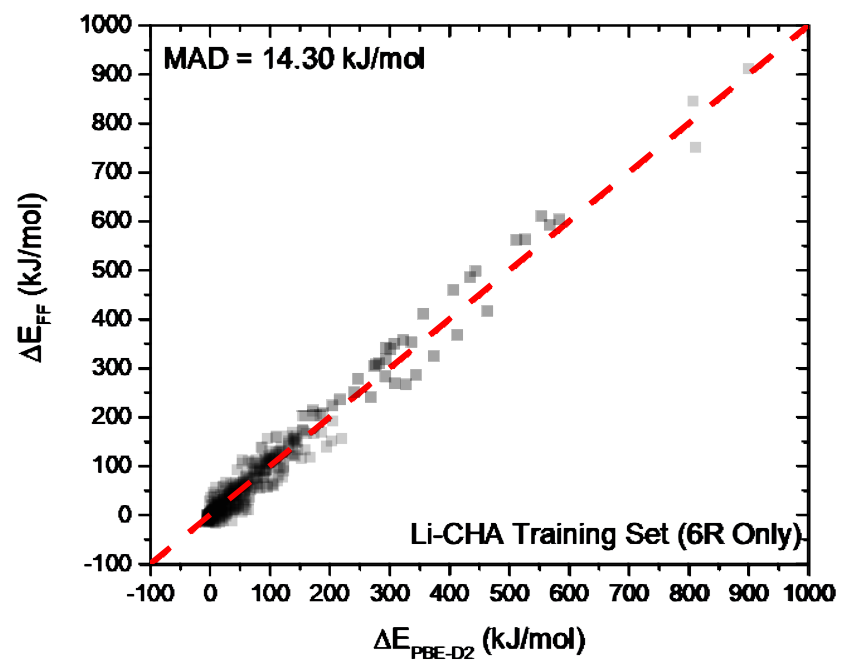

Figure S2. A comparison between PBE-D2 energies and FF energies that were fit to the PBE-D2 energies in Li-CHA. The label "6R Only" refers to the cation distribution in Li-CHA, where almost all cations are observed to occupy 6MR positions.

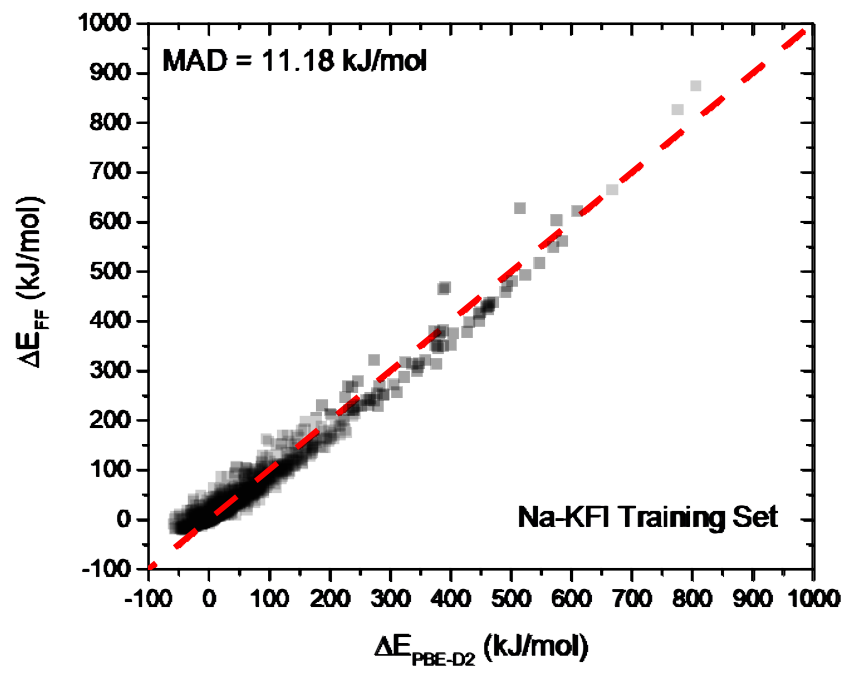

Figure S3. A comparison between PBE-D2 energies and FF energies that were fit to the PBE-D2 energies for this set of configurations in Na-KFI. 


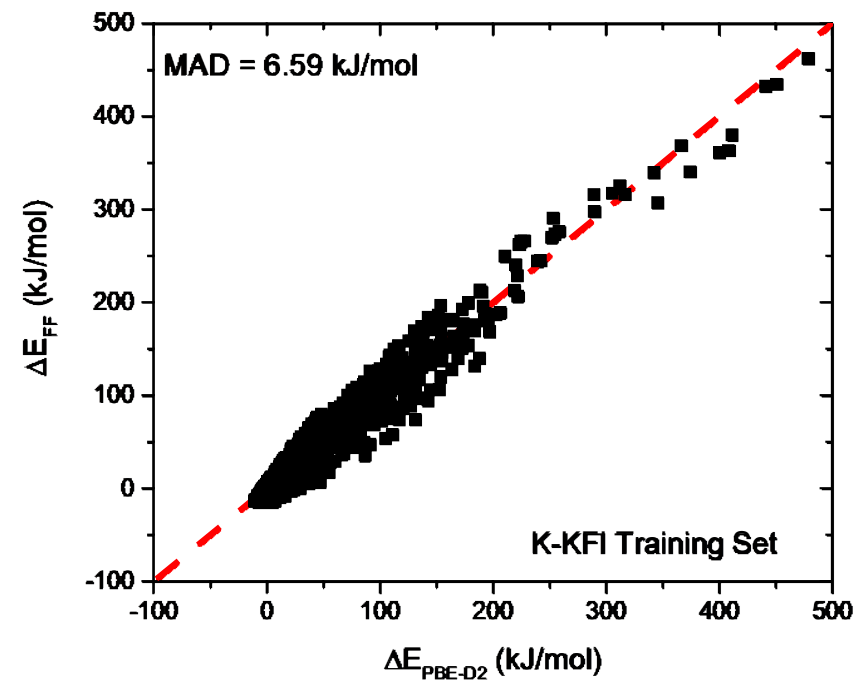

Figure S4. A comparison between PBE-D2 energies and FF energies that were fit to the PBE-D2 energies for this set of configurations in K-KFI.

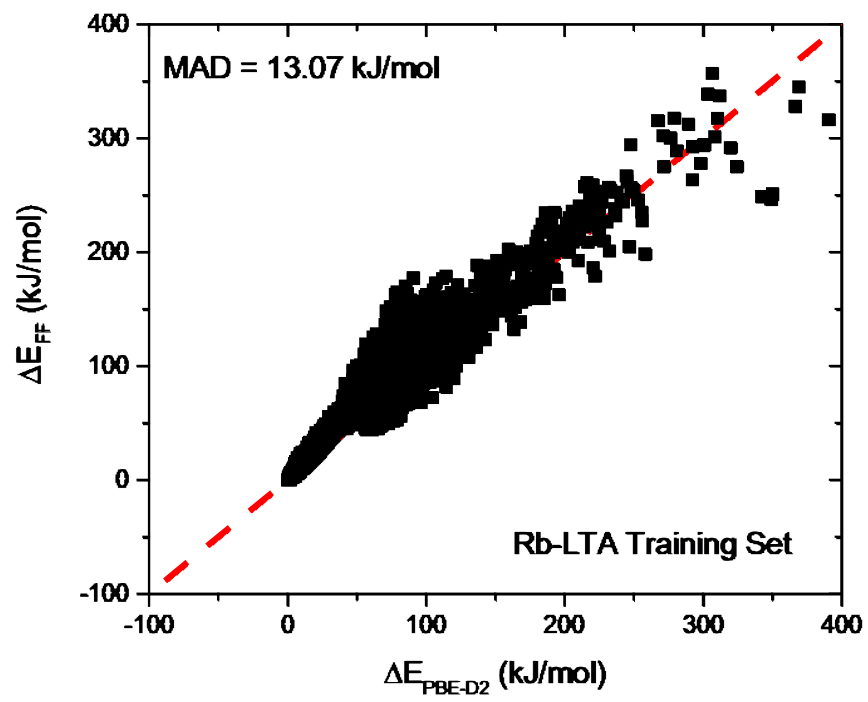

Figure S5. A comparison between PBE-D2 energies and FF energies that were fit to the PBE-D2 energies for this set of configurations in Rb-LTA. 


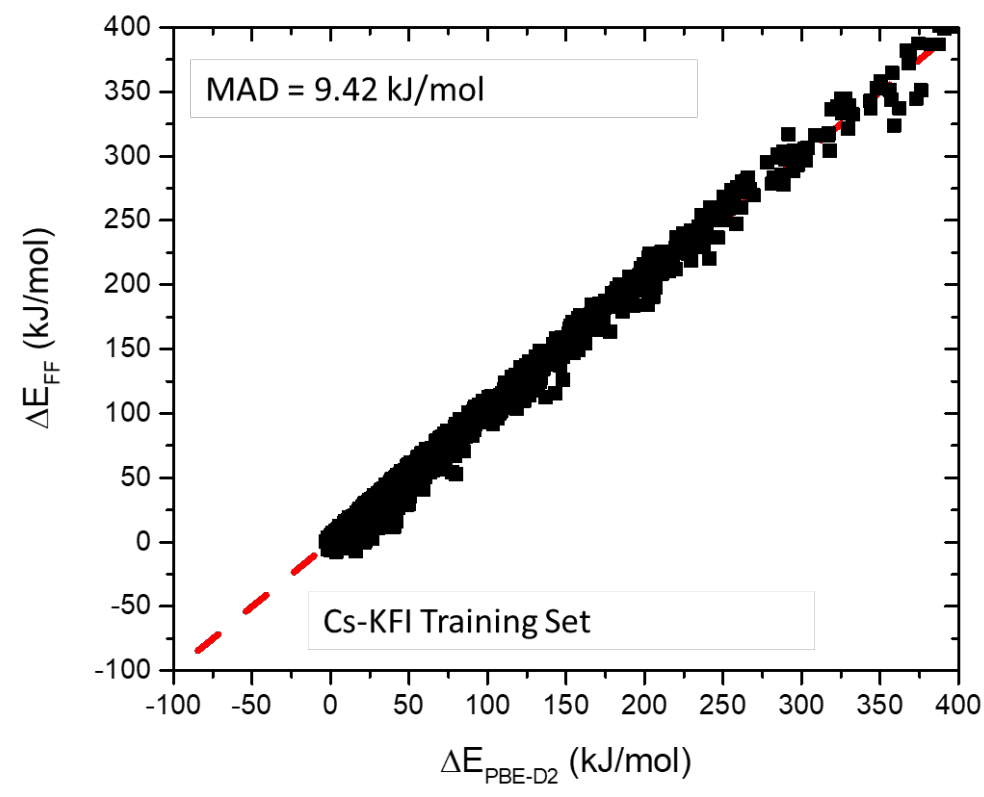

Figure S6. A comparison between PBE-D2 energies and FF energies that were fit to the PBE-D2 energies for this set of configurations in Cs-KFI.

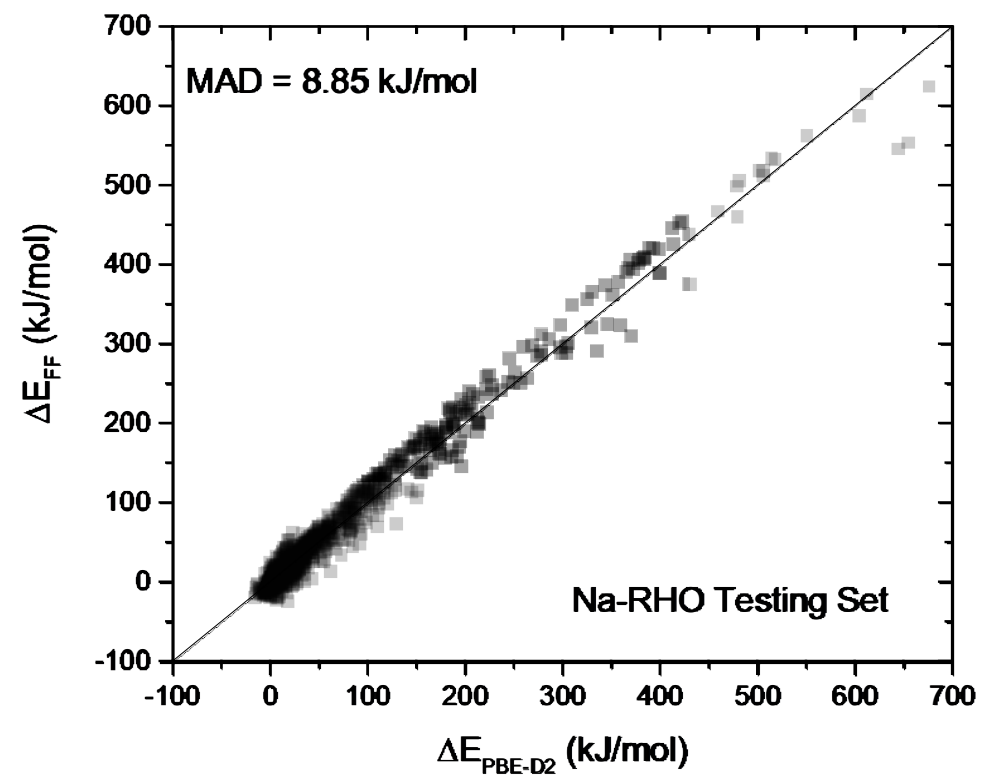

Figure S7. A comparison between PBE-D2 energies and energies calculated using the CCFF for different Na-distributions in Na-RHO. 
Table S7. A comparison between simulated and experimental cation positions in Na-LTA $(\mathrm{Si} / \mathrm{Al}=1)$. The experimental data was taken from Pluth and $\mathrm{Smith}^{8}$.

\begin{tabular}{llll}
\hline Na-LTA(Si/Al=1) & 8 MR & $6 \mathrm{MR}$ & $4 \mathrm{MR}$ \\
\hline Simulated & 24 & 64 & 8 \\
Expt. (Pluth and Smith) & 24 & 64 & 8 \\
\hline
\end{tabular}

Table S8. A comparison between three sets of simulated cation positions and one set of experimental cation positions in $\mathrm{Na}-\mathrm{FAU}(\mathrm{Si} / \mathrm{Al}=2.5)$ is shown. The experimental data was taken from Jirak et al. ${ }^{9}$

\begin{tabular}{llllll}
\hline Na-FAU(Si/Al=2.5) & SI & SI & SII & SIII & Total \\
\hline Simulated (Sparse) & 16 & 3 & 31 & 5 & 55 \\
Simulated (Random) & 18 & 1 & 29 & 7 & 55 \\
Simulated (Clustered) & 0 & 16 & 25 & 14 & 55 \\
Expt (Jirak et al.) & 18 & 4 & 32 & 1 & 55 \\
\hline
\end{tabular}

Table S9. A comparison between experimental and simulated cation positions in K-LTA $(\mathrm{Si} / \mathrm{Al}=2)$. The experimental results were taken from Ikeda et al. ${ }^{10}$

\begin{tabular}{llll}
\hline K-LTA(Si/Al=2) & $8 \mathrm{MR}$ & $6 \mathrm{MR}$ & $4 \mathrm{MR}$ \\
\hline${\text { Expt. (Ikeda et al. })^{10}}^{24}$ & 40 & 0 \\
Simulated & 21 & 43 & 0 \\
\hline
\end{tabular}

Table S10. A comparison between two sets of experimental cation positions with simulated cation positions in K-FAU ( $\mathrm{Si} / \mathrm{Al}=2.5)$. The experimental results were taken from Mortier et al. ${ }^{11}$ and Van Dun et al. ${ }^{12}$

\begin{tabular}{|c|c|c|c|c|c|}
\hline $\mathrm{K}-\mathrm{FAU}(\mathrm{Si} / \mathrm{Al}=2.5)$ & SI & SI' & SII & SIII & Total \\
\hline Simulated & 12 & 3 & 28 & 13 & 56 \\
\hline Expt. (Mortier et al., 1972) ${ }^{11}$ & 5 & 18 & 27 & 4 & 54 \\
\hline Expt. (Van Dun et al., 1985) 12 & 6.5 & 6.5 & 30 & 13 & 56 \\
\hline
\end{tabular}

Table S11. A comparison between experimental and simulated cation positions in Cs$\mathrm{RHO}(\mathrm{Si} / \mathrm{Al}=3.9)$. The experimental results were taken from Losinzka et al. ${ }^{13}$

\begin{tabular}{llll}
\hline Cs-RHO (Si/Al=3.9) & D8R & S8R & $6 \mathrm{R}$ \\
\hline Expt. (Lozinska et al.) & 24 & 0 & 56 \\
Simulated & 21 & 0 & 59 \\
\hline
\end{tabular}




\section{S3. Additional Adsorption Validation and Aluminum Distribution Effects}
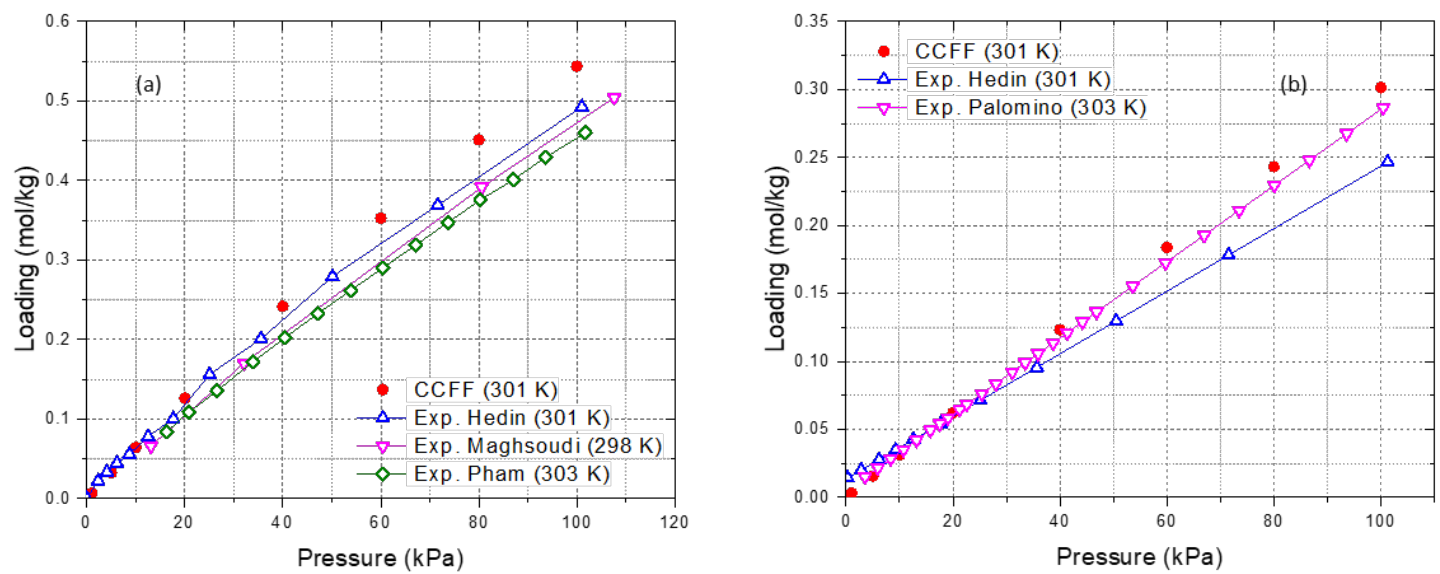

Figure S8. Simulated adsorption isotherms for the CCFF for all-atom $\mathrm{CH}_{4}$ are compared to experimental adsorption isotherms in (a) pure-silica CHA ${ }^{14-16}$ and (b) pure-silica LTA ${ }^{14,17}$. 

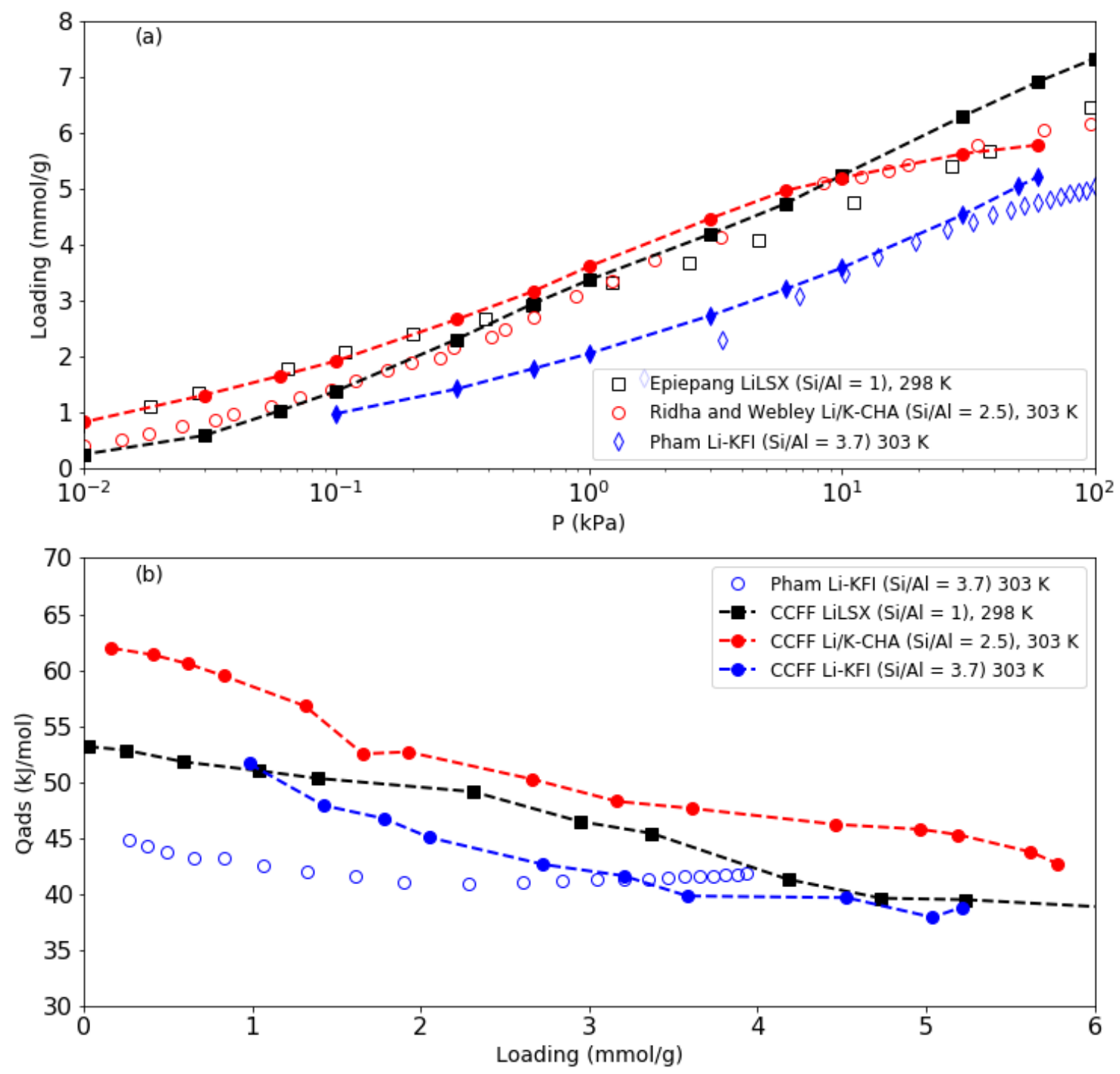

Figure S9. A comparison of simulated (closed symbols) and experimental (open symbols) (a) adsorption isotherms and (b) heats of adsorption for Li-LSX (black), Li/K -CHA (red), and LiKFI (blue). The experimental data for Li-LSX was taken from Epiepang et $\mathrm{al}^{18}$. The experimental data for $\mathrm{Li} / \mathrm{K}-\mathrm{CHA}$ was taken from Ridha and Webley ${ }^{19}$. The experimental data for Li-KFI was taken from Pham et al. ${ }^{20}$ 

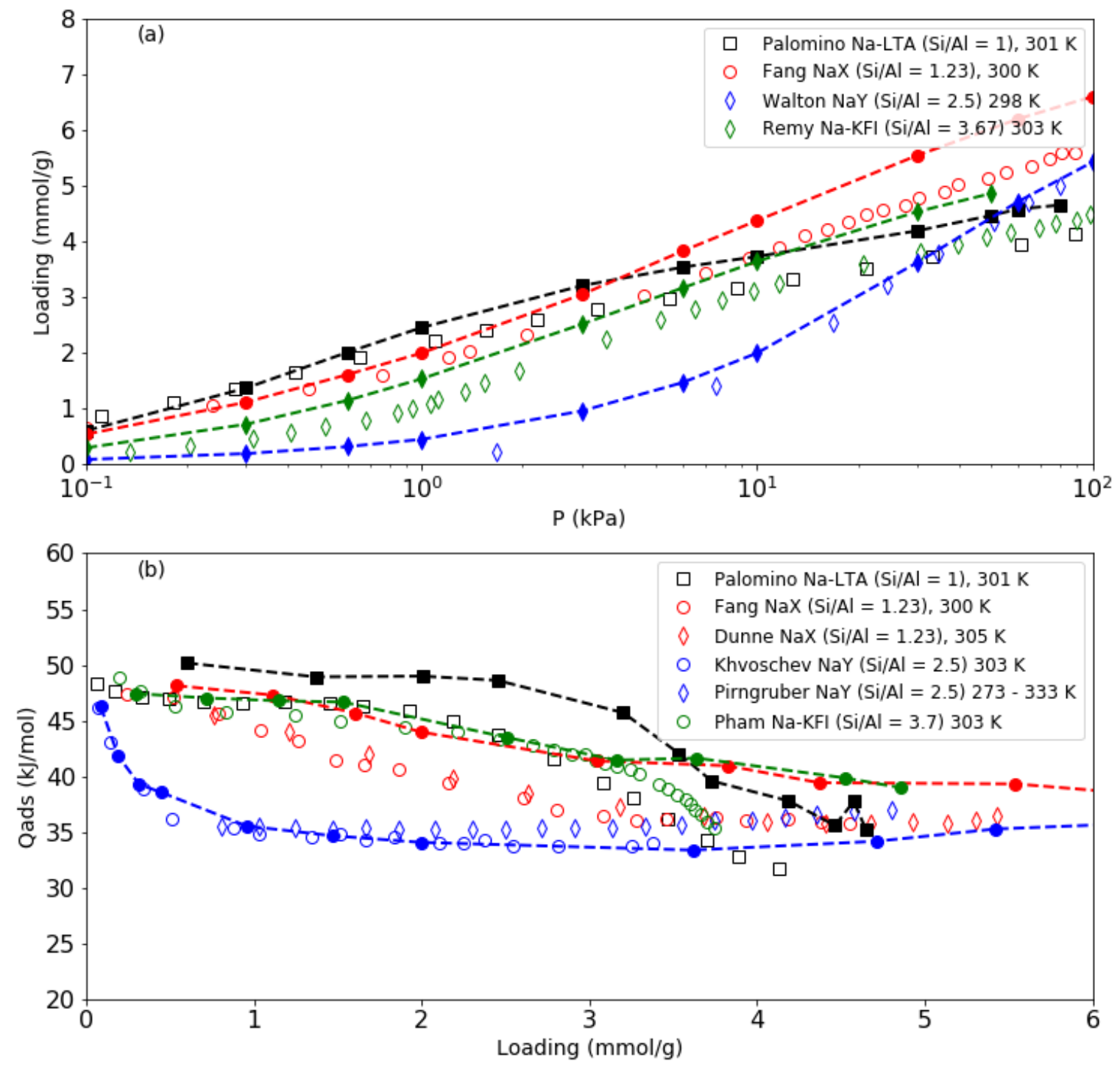

Figure S10. A comparison of simulated (closed symbols) and experimental (open symbols) (a) adsorption isotherms and (b) heats of adsorption for Na-LTA (black), NaX (red), NaY (blue) and Na-KFI (green) are shown. The experimental data for Na-LTA was taken from Palomino et al. ${ }^{17}$ $\mathrm{NaX}$ experimental data was taken from Fang et al. ${ }^{21}$ and Dunne et al. ${ }^{22} \mathrm{NaY}$ experimental data was taken from Walton et al. ${ }^{23}$, Khvoschev et al. ${ }^{24}$ and Pirngruber at al. ${ }^{25}$, KFI experimental data is taken from Remy et al. ${ }^{26}$ and Pham et al. ${ }^{20}$ 

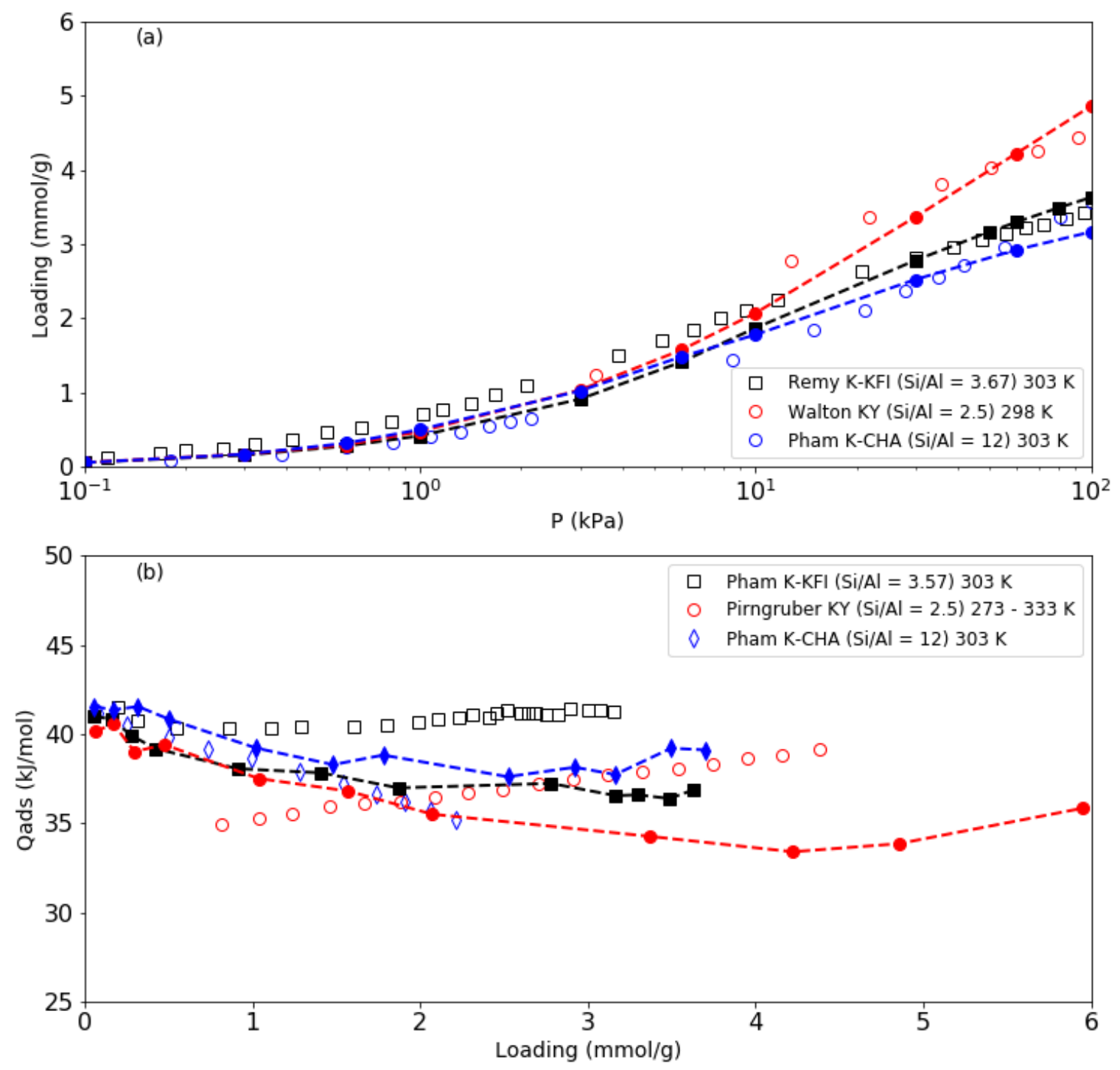

Figure S11. A comparison of simulated (closed symbols) and experimental (open symbols) (a) adsorption isotherms and (b) heats of adsorption for K-KFI (black), KY (red), and K-CHA (Si/Al $=12$ ) (blue) are shown. The experimental data for K-KFI was taken from Remy et al. ${ }^{26}$ and Pham et al. ${ }^{27}$. KY experimental data was taken from Walton et al. ${ }^{23}$ and Pirngruber et al. ${ }^{25}$ 

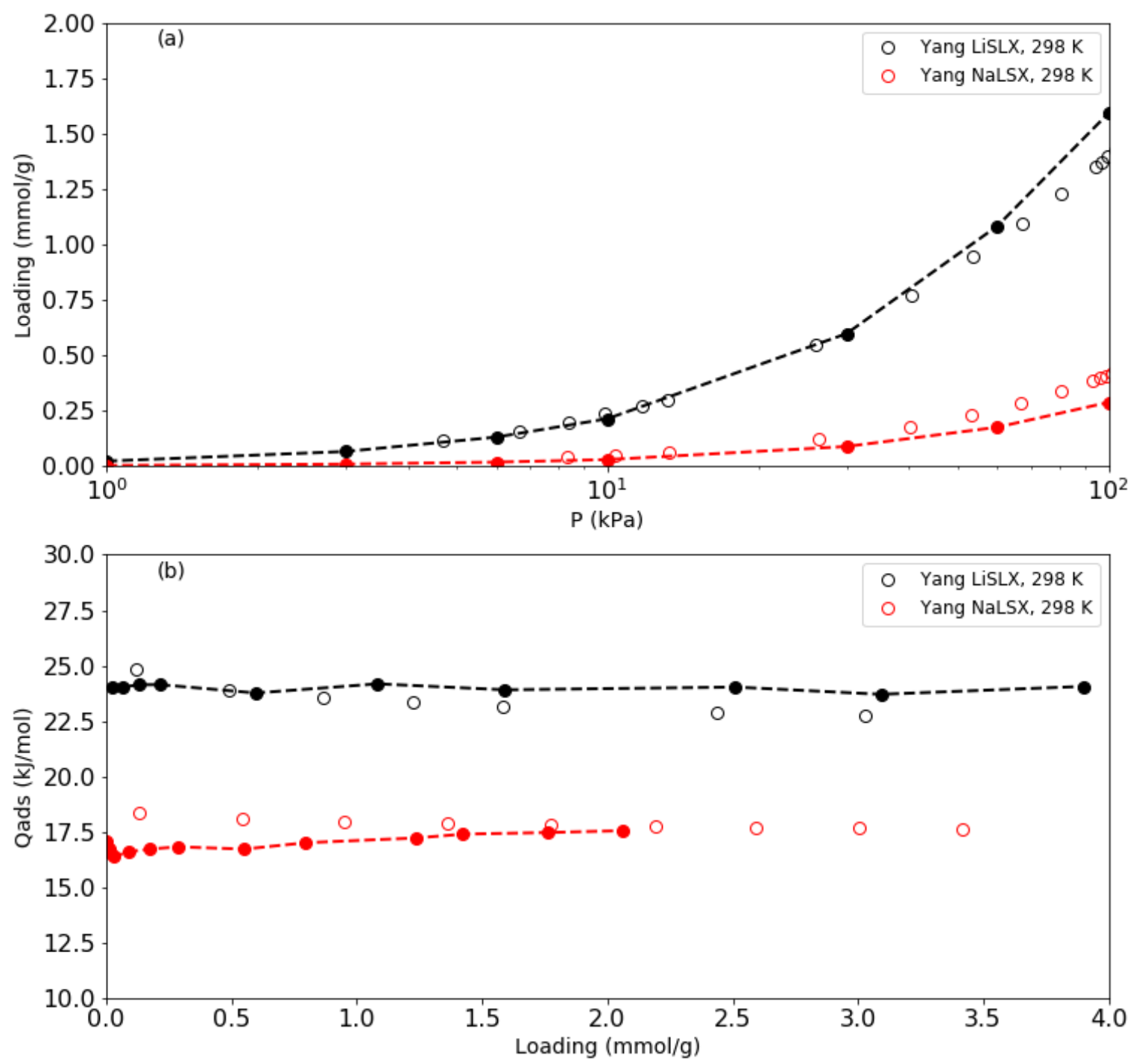

Figure S12. A comparison of simulated and experimental $\mathrm{N}_{2}$ (a) adsorption isotherms and (b) heats of adsorption in Li-LSX (black) and Na-LSX (red). The experimental data was taken from Yang et al. ${ }^{28}$ 

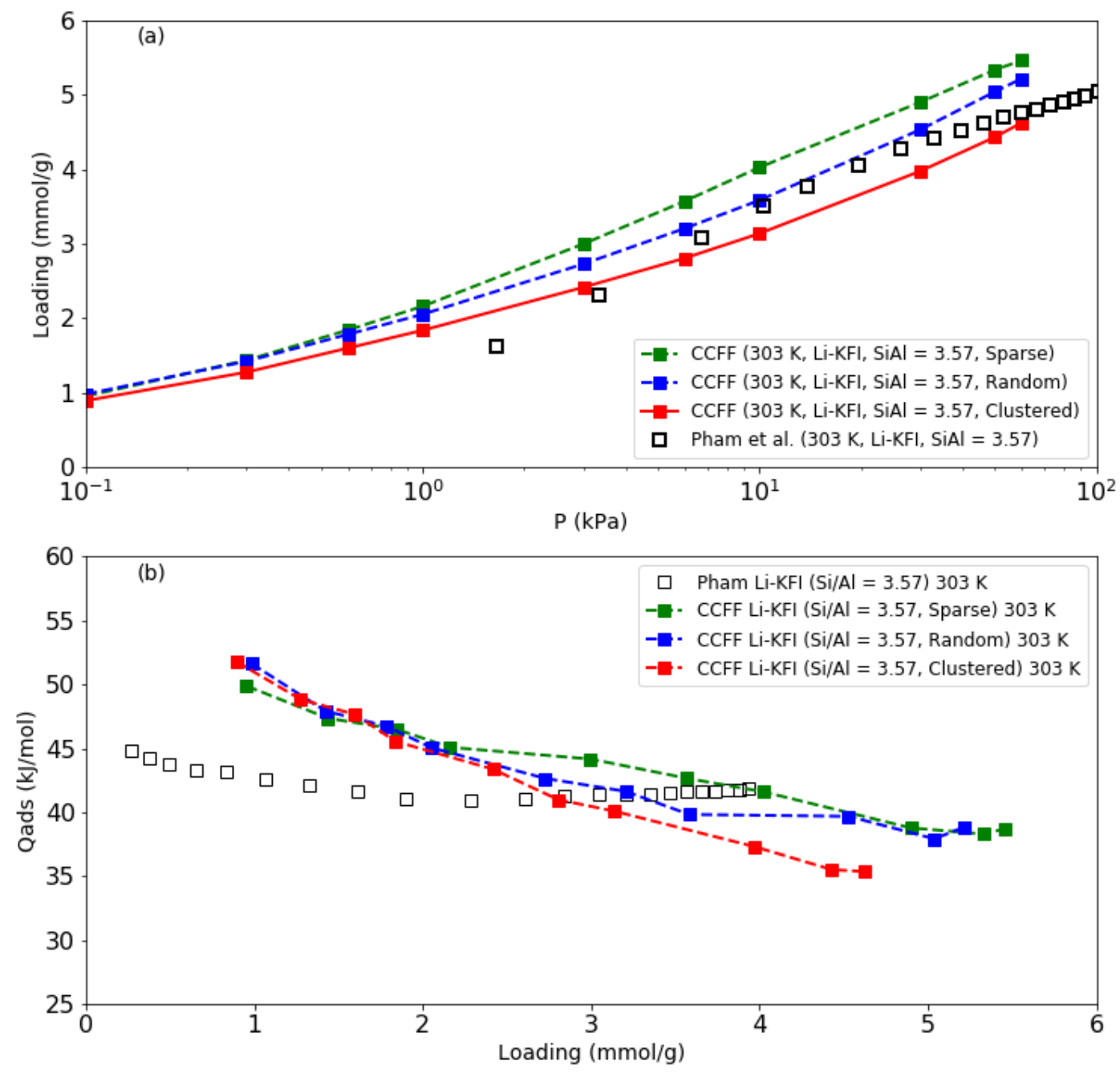

Figure S13. A comparison of simulated (filled symbols) $\mathrm{CO}_{2}$ (a) adsorption isotherms and (b) heats of adsorption with experimental (open symbols) data ${ }^{20}$ in $\mathrm{Li}-\mathrm{KFI}(\mathrm{Si} / \mathrm{Al}=3.57$ ). GCMC simulations using sparse (green), random (blue) and clustered (red) Al distributions were performed. Nonrandom Al distributions were generated using the methods of Findley et al. ${ }^{29}$. 

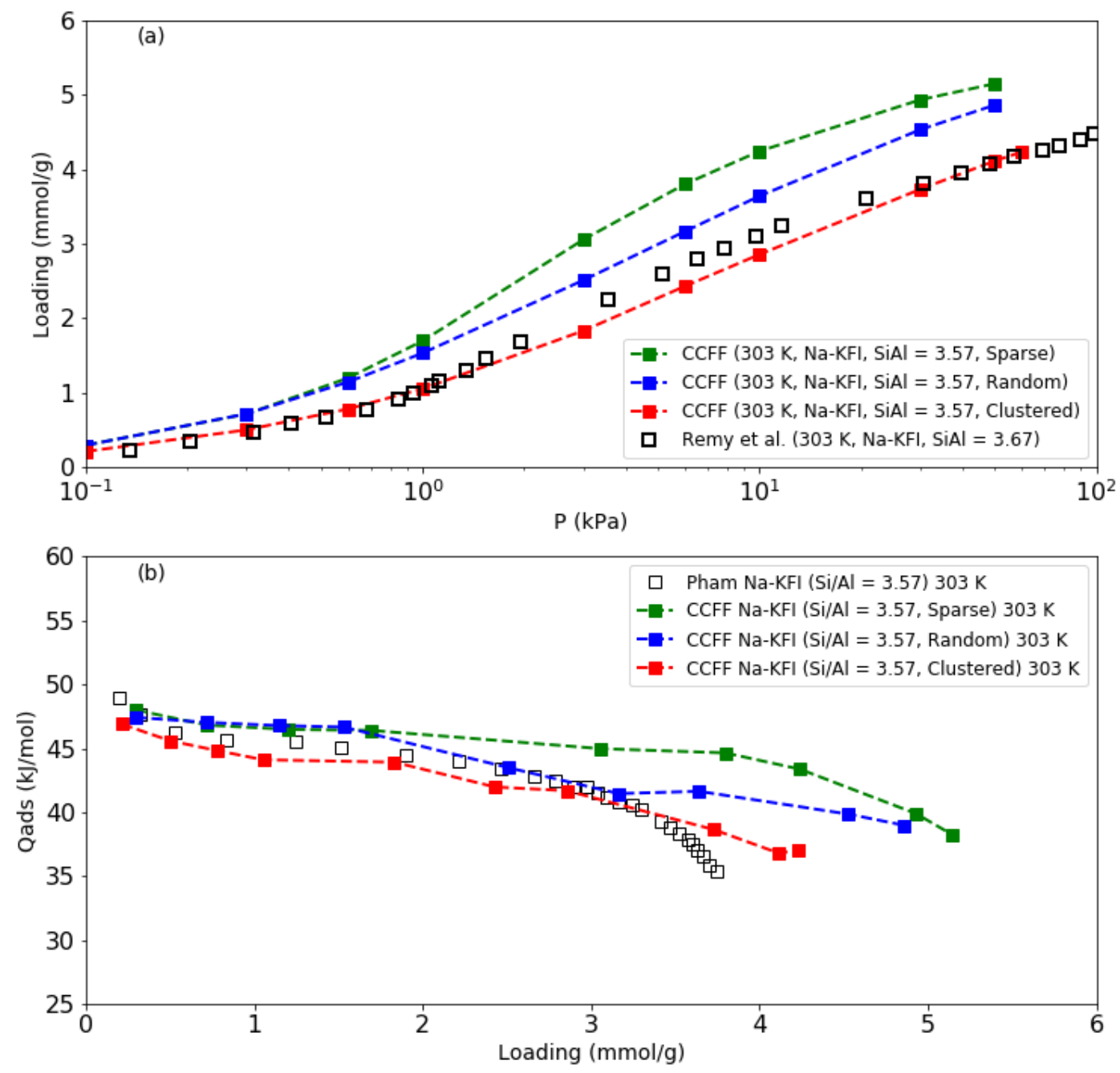

Figure S14. A comparison of simulated (filled symbols) $\mathrm{CO}_{2}$ (a) adsorption isotherms and (b) heats of adsorption with experimental (open symbols) data ${ }^{20}$ in $\mathrm{Na}-\mathrm{KFI}(\mathrm{Si} / \mathrm{Al}=3.57)$. GCMC simulations using sparse (green), random (blue) and clustered (red) Al distributions were performed. Nonrandom Al distributions were generated using the methods of Findley et al. ${ }^{29}$. 

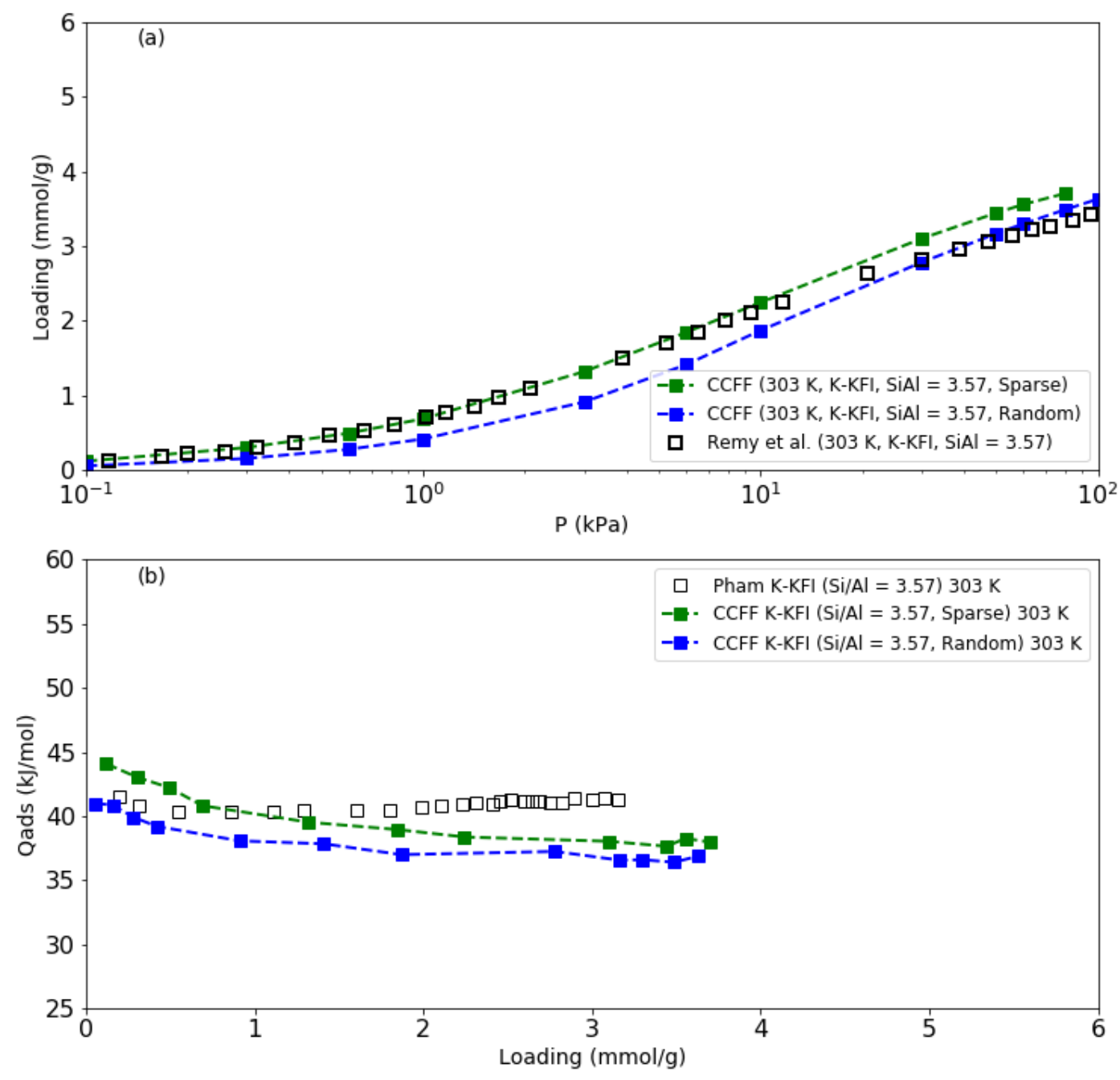

Figure S15. A comparison of simulated (filled symbols) $\mathrm{CO}_{2}$ (a) adsorption isotherms and (b) heats of adsorption with experimental (open symbols) data ${ }^{20}$ in $\mathrm{K}-\mathrm{KFI}(\mathrm{Si} / \mathrm{Al}=3.57)$. GCMC simulations using sparse (green) and random (blue) Al distributions were performed. Nonrandom Al distributions were generated using the methods of Findley et al. ${ }^{29}$. 


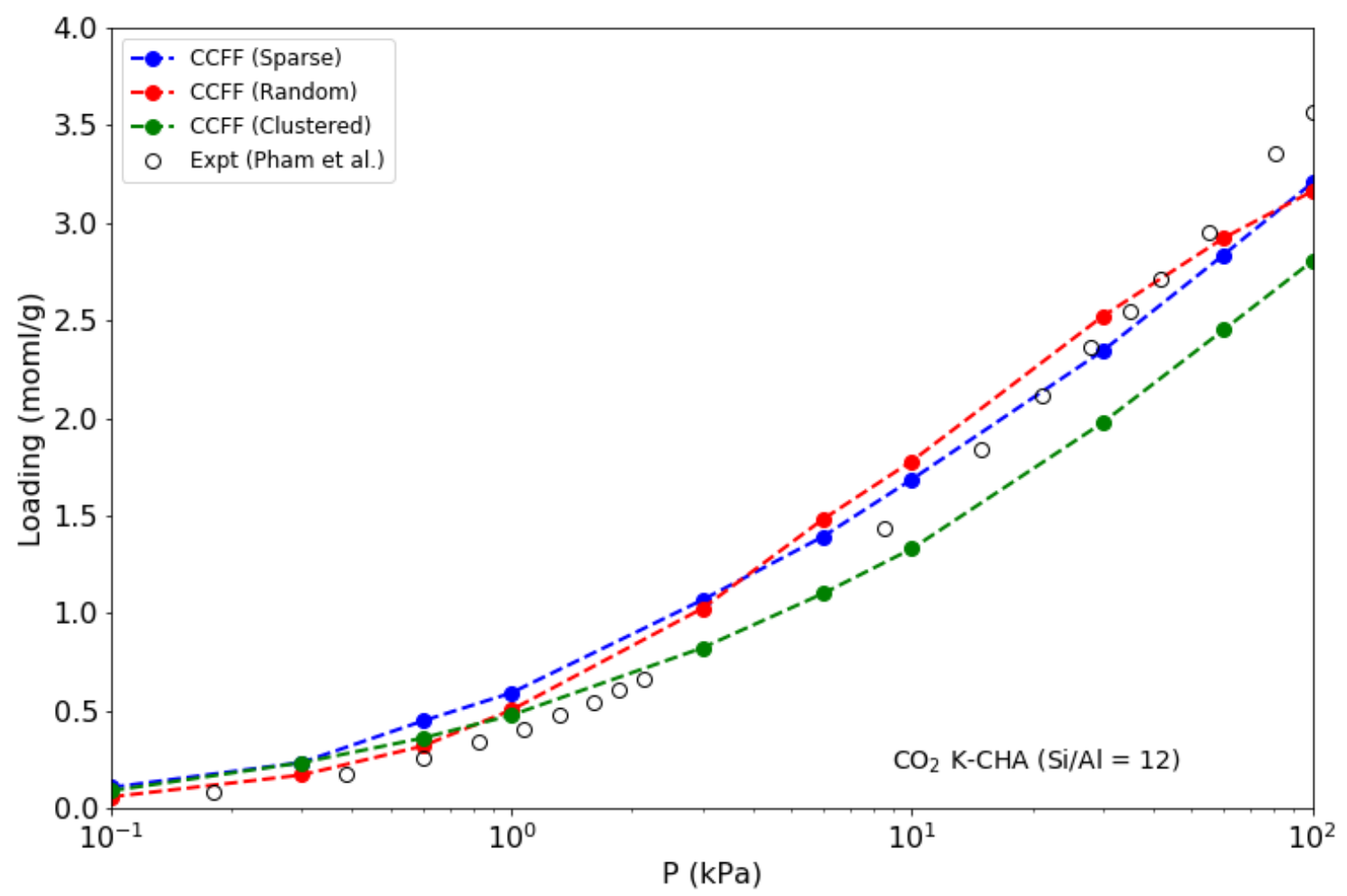

Figure S16. A comparison of simulated (filled symbols) $\mathrm{CO}_{2}$ adsorption isotherms with experimental $^{27}$ (open symbols) adsorption isotherms in $\mathrm{K}-\mathrm{CHA}(\mathrm{Si} / \mathrm{Al}=12)$. GCMC simulations using sparse (green), random (blue) and clustered (red) Al distributions were performed. Nonrandom Al distributions were generated using the methods of Findley et al. ${ }^{29}$. 

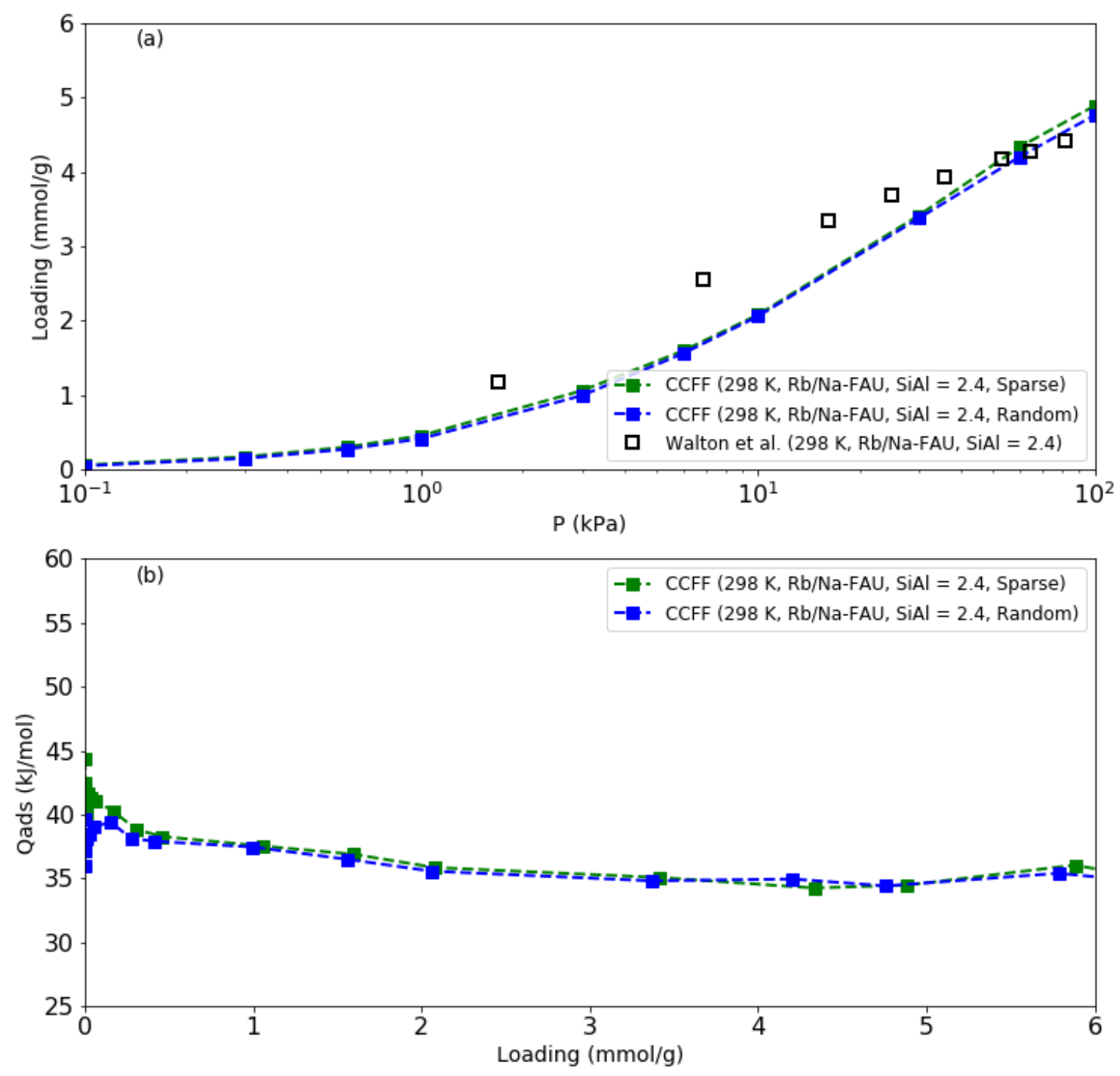

Figure S17. A comparison of simulated (filled symbols) $\mathrm{CO}_{2}$ (a) adsorption isotherms with experimental (open symbols) adsorption isotherms ${ }^{23}$ in $\mathrm{Rb} / \mathrm{Na}-\mathrm{FAU}(\mathrm{Si} / \mathrm{Al}=2.4$ ). GCMC simulations using sparse (green) and random (blue) Al distributions were performed. The dependence of isosteric heat of adsorption on Al-distribution is shown in (b). Nonrandom Al distributions were generated using the methods of Findley et al. ${ }^{29}$. 

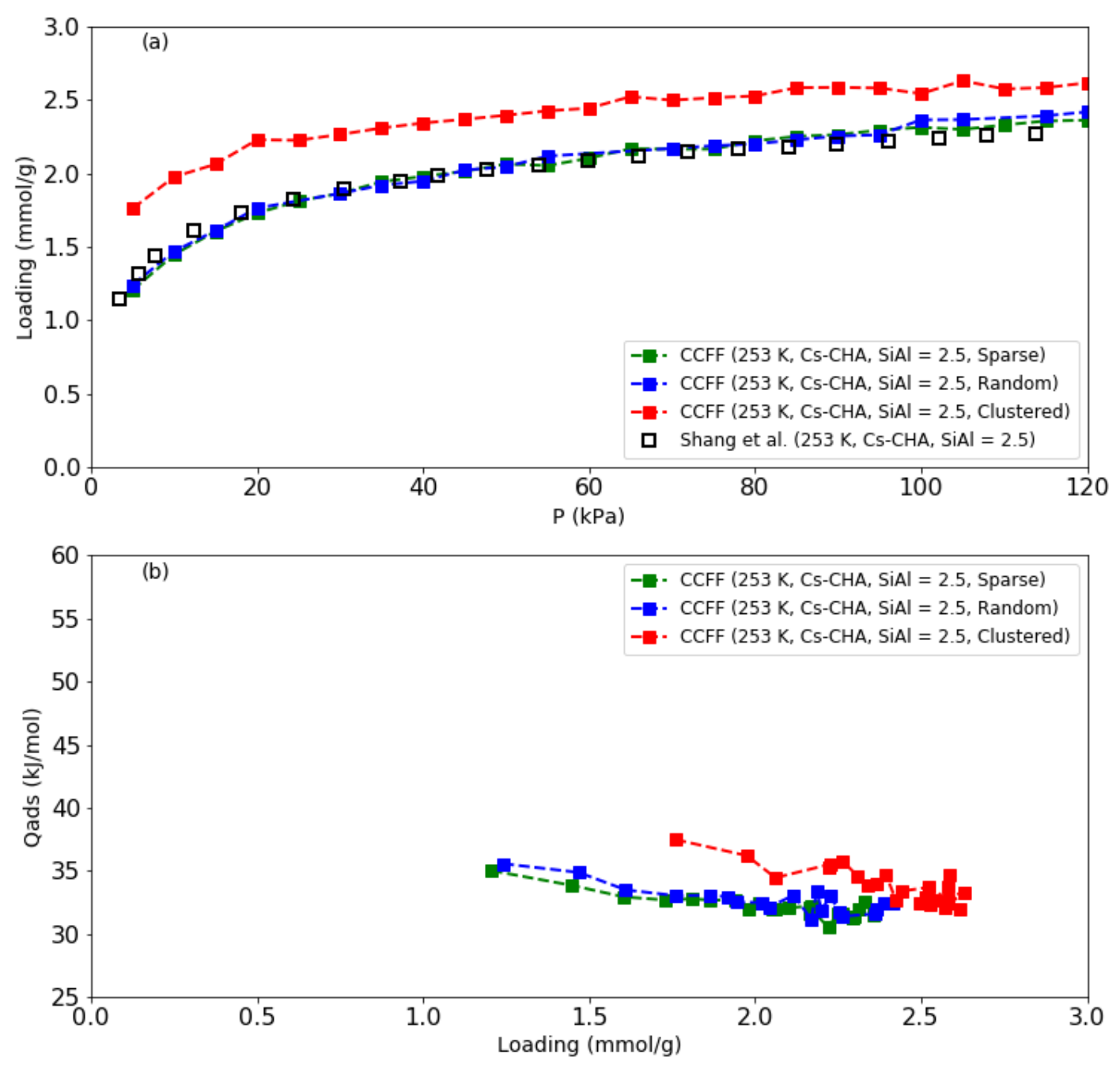

Figure S18. A comparison of simulated (filled symbols) $\mathrm{CO}_{2}$ (a) adsorption isotherms with experimental (open symbols) adsorption isotherms ${ }^{30}$ in $\mathrm{Cs}-\mathrm{CHA}(\mathrm{Si} / \mathrm{Al}=2.5)$. GCMC simulations using sparse (green), random (blue), and clustered (red) Al distributions were performed. The dependence of isosteric heats of adsorption on Al-distribution is shown in (b). Nonrandom Al distributions were generated using the methods of Findley et al. ${ }^{29}$. 

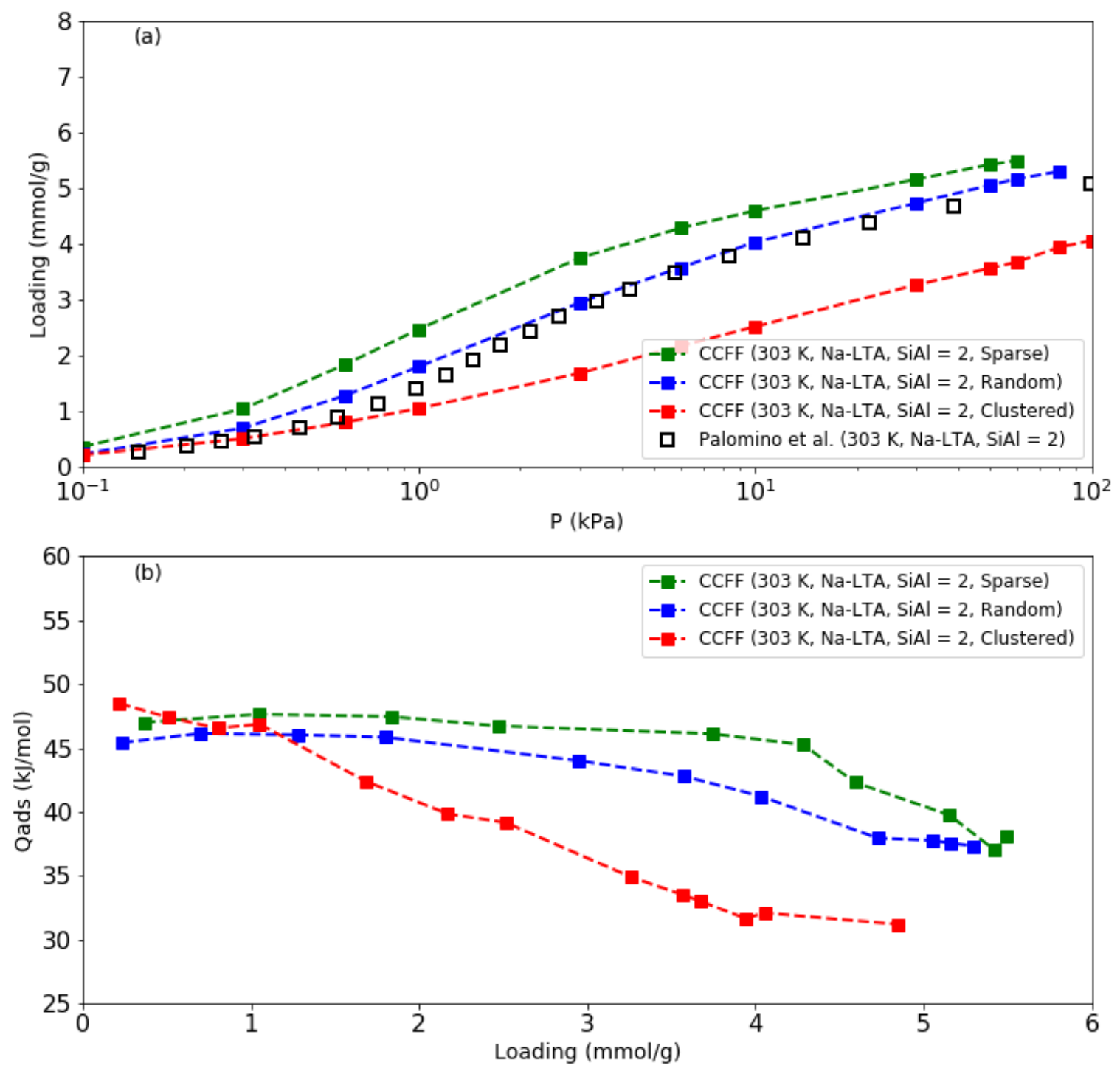

Figure S19. A comparison of simulated (filled symbols) $\mathrm{CO}_{2}$ (a) adsorption isotherms with experimental (open symbols) adsorption isotherms ${ }^{17}$ in Na-LTA ( $\mathrm{Si} / \mathrm{Al}=2$ ). GCMC simulations using sparse (green), random (blue), and clustered (red) Al distributions were performed. The dependence of isosteric heats of adsorption on Al-distribution is shown in (b). Nonrandom Al distributions were generated using the methods of Findley et al. ${ }^{29}$. 


\section{S4. Additional Diffusion Validation}

Table S12. List of forcefields from the literature ${ }^{31-43}$ used for diffusion predictions of $\mathrm{CO}_{2}, \mathrm{~N}_{2}$, and $\mathrm{CH}_{4}$ in Na-exchanged zeolites in Figures S20-S24.

\begin{tabular}{|c|c|c|c|c|}
\hline Force Field & Molecules & Si/Al Ratio & Si \& Al vdW & Cation Mobility* \\
\hline Akten et al. ${ }^{31}$ & $\mathrm{CO}_{2}, \mathrm{~N}_{2}$ & Fixed & No & Mobile \\
\hline Vujić et al. ${ }^{32}$ & $\mathrm{CO}_{2}, \mathrm{~N}_{2}, \mathrm{O}_{2}$ & Variable & Yes & Mobile \\
\hline Newsome et al. ${ }^{33}$ & $\mathrm{CO}_{2}, \mathrm{~N}_{2}$ & Variable & No & Fixed \\
\hline Martin-Calvo et al. ${ }^{34}$ & $\mathrm{CH}_{4}, \mathrm{~N}_{2}, \mathrm{O}_{2}$ & Variable & No & Mobile \\
\hline Maurin et al. ${ }^{35}$ & $\mathrm{CO}_{2}$ & Variable & No & Fixed \\
\hline Sethia et al. ${ }^{36}$ & $\mathrm{CH}_{4}, \mathrm{~N}_{2}, \mathrm{O}_{2}$ & Variable & No & Mobile \\
\hline Strzempek et al. ${ }^{37}$ & $\mathrm{CH}_{4}$ & Variable & No & Mobile \\
\hline Fang et al. ${ }^{38}$ & $\mathrm{CO}_{2}$ & Variable & Yes & Mobile \\
\hline García-Sánchez et al. ${ }^{39}$ & $\mathrm{CO}_{2}$ & Variable & No & Mobile \\
\hline Jaramillo et al. ${ }^{40}$ & $\mathrm{CO}_{2}$ & Fixed & No & Fixed \\
\hline Calero et al. ${ }^{41}$ & $\mathrm{CH}_{4}$ & Variable & No & Mobile \\
\hline Yang et al. ${ }^{42}$ & $\mathrm{CO}_{2}$ & Variable & No & Mobile \\
\hline Pillai et al. ${ }^{43}$ & $\mathrm{CH}_{4}, \mathrm{~N}_{2}$ & Fixed & No & Fixed \\
\hline
\end{tabular}

*FFs with fixed cations were not used for diffusion predictions in small pore zeolites. 


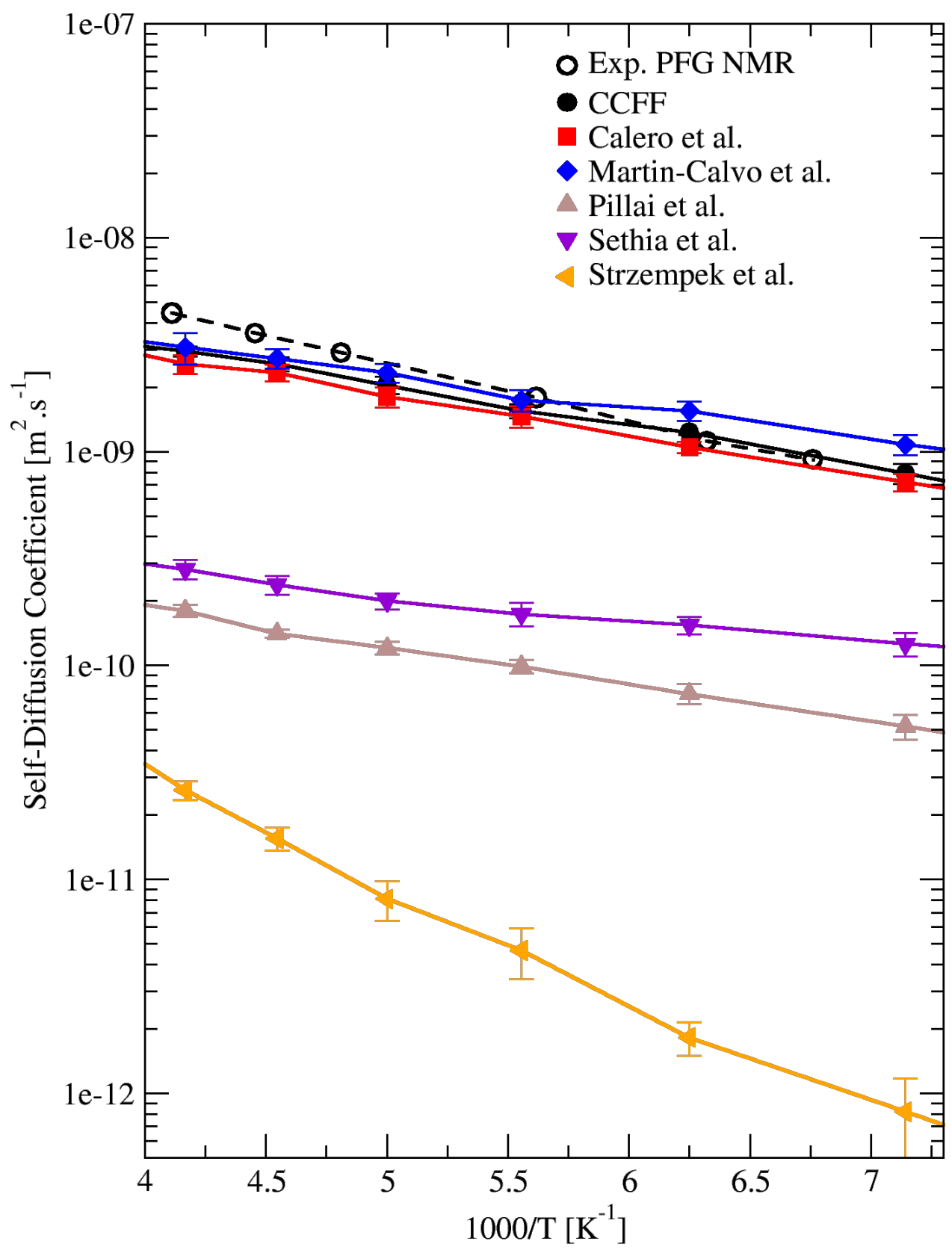

Figure S20. Temperature dependence of self-diffusion of $\mathrm{CH}_{4}$ in $\mathrm{NaX}$ with $\mathrm{Si} / \mathrm{Al}=1.23$ at a loading of 78 molecules per unit cell using CCFF and other FFs from the literature (filled symbols). The predictions are compared to PFG NMR experimental measurements of Kärger et $\mathrm{al} .{ }^{44}$ at the same loading in $\mathrm{NaX}$ with $\mathrm{Si} / \mathrm{Al}=1.1-1.3$ (open symbols). 


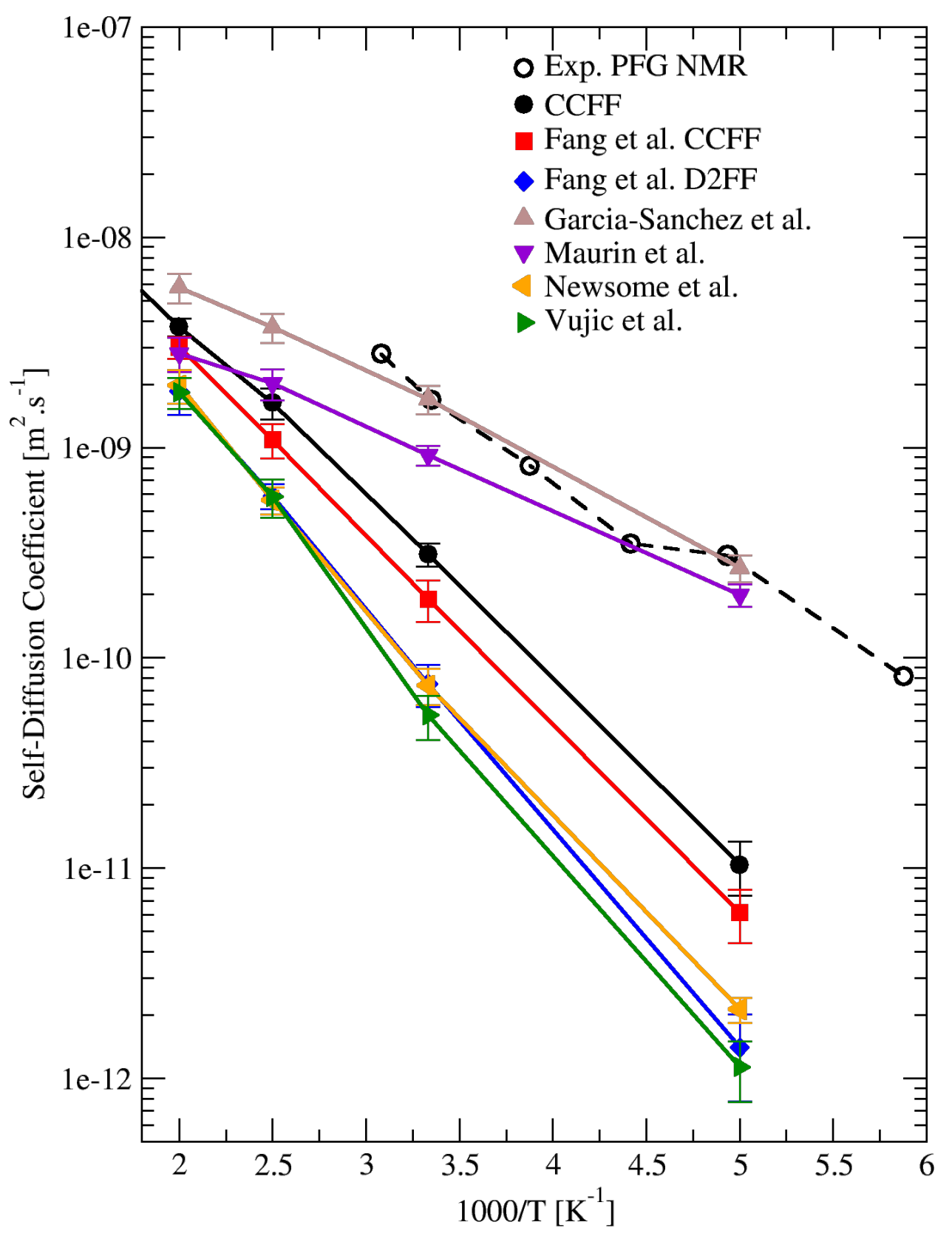

Figure S21. Temperature dependence of self-diffusion of $\mathrm{CO}_{2}$ in $\mathrm{NaX}$ with $\mathrm{Si} / \mathrm{Al}=1.23$ at a loading of 30 molecules per unit cell using CCFF and other FFs from the literature (filled symbols). The predictions are compared to PFG NMR experimental measurements of Kärger et al. ${ }^{45}$ at a loading between 24-32 molecules per unit cell in $\mathrm{NaX}$ (open symbols). 


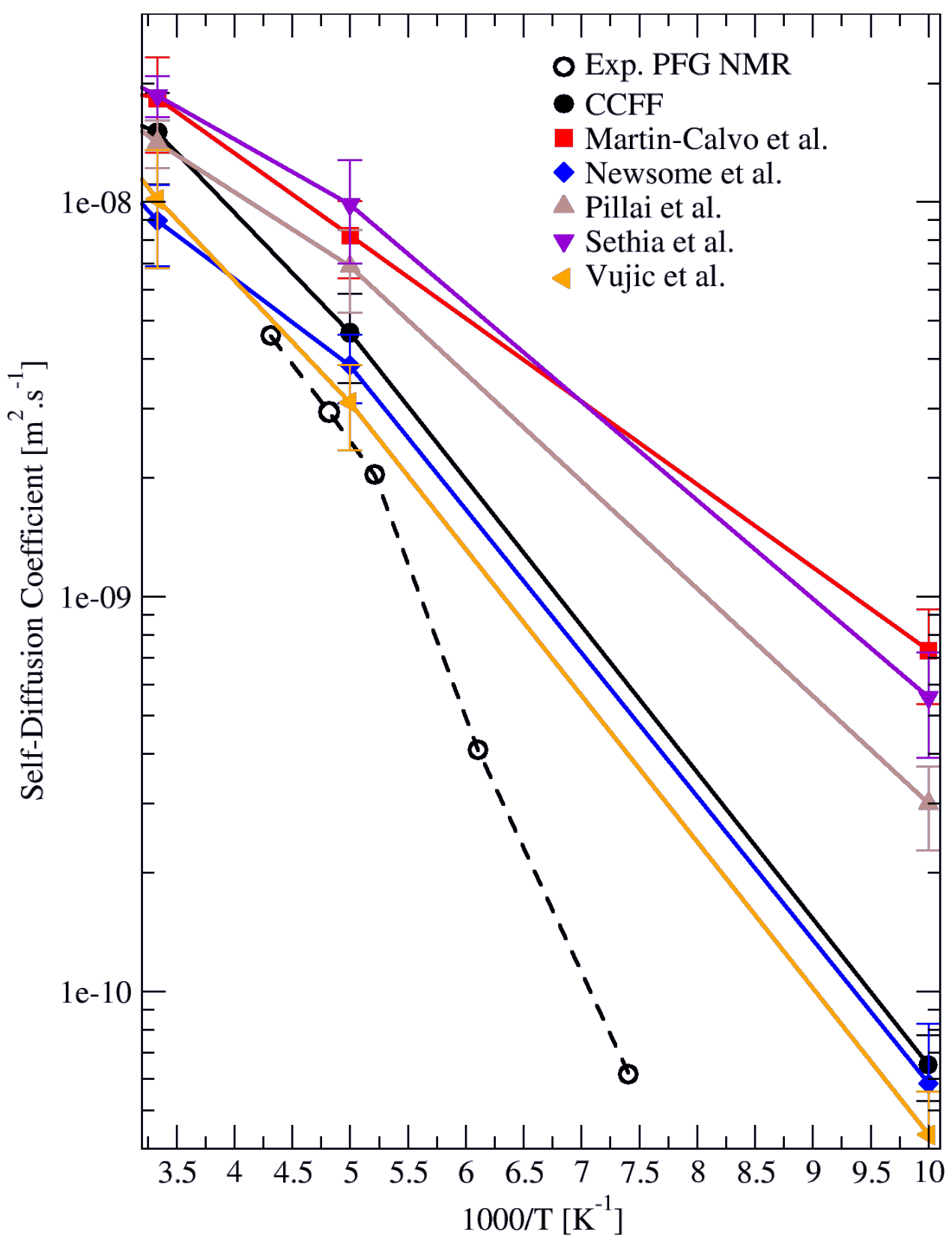

Figure S22. Temperature dependence of self-diffusion of $\mathrm{N}_{2}$ in $\mathrm{NaX}$ with $\mathrm{Si} / \mathrm{Al}=1.23$ at a loading of 10 molecules per unit cell using CCFF and other FFs from the literature (filled symbols). The predictions are compared to PFG NMR experimental measurements of Bär et al. ${ }^{46}$ at a loading between 10.4 molecules per unit cell in $\mathrm{NaX}$ (open symbols). 


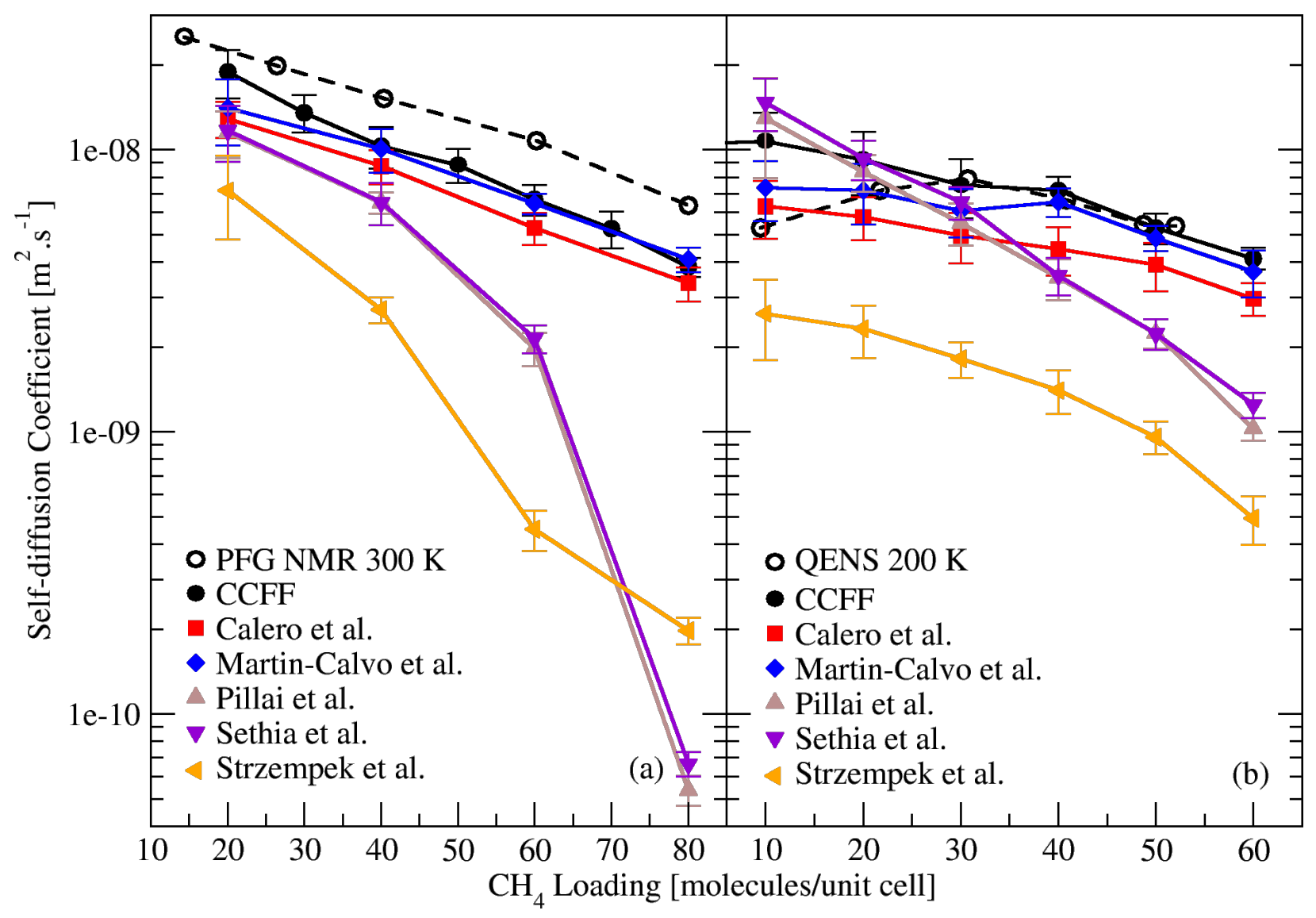

Figure S23. Loading dependence of $\mathrm{CH}_{4}$ in (a) $\mathrm{NaX}$ with $\mathrm{Si} / \mathrm{Al}=1.23$ at $300 \mathrm{~K}$ and in (b) $\mathrm{NaY}$ at $200 \mathrm{~K}$ using CCFF and other FFs from the literature (filled symbols). Experimental PFG NMR and QENS data are from Caro et al. ${ }^{47}$ and Déroche et al. ${ }^{48}$, respectively. 


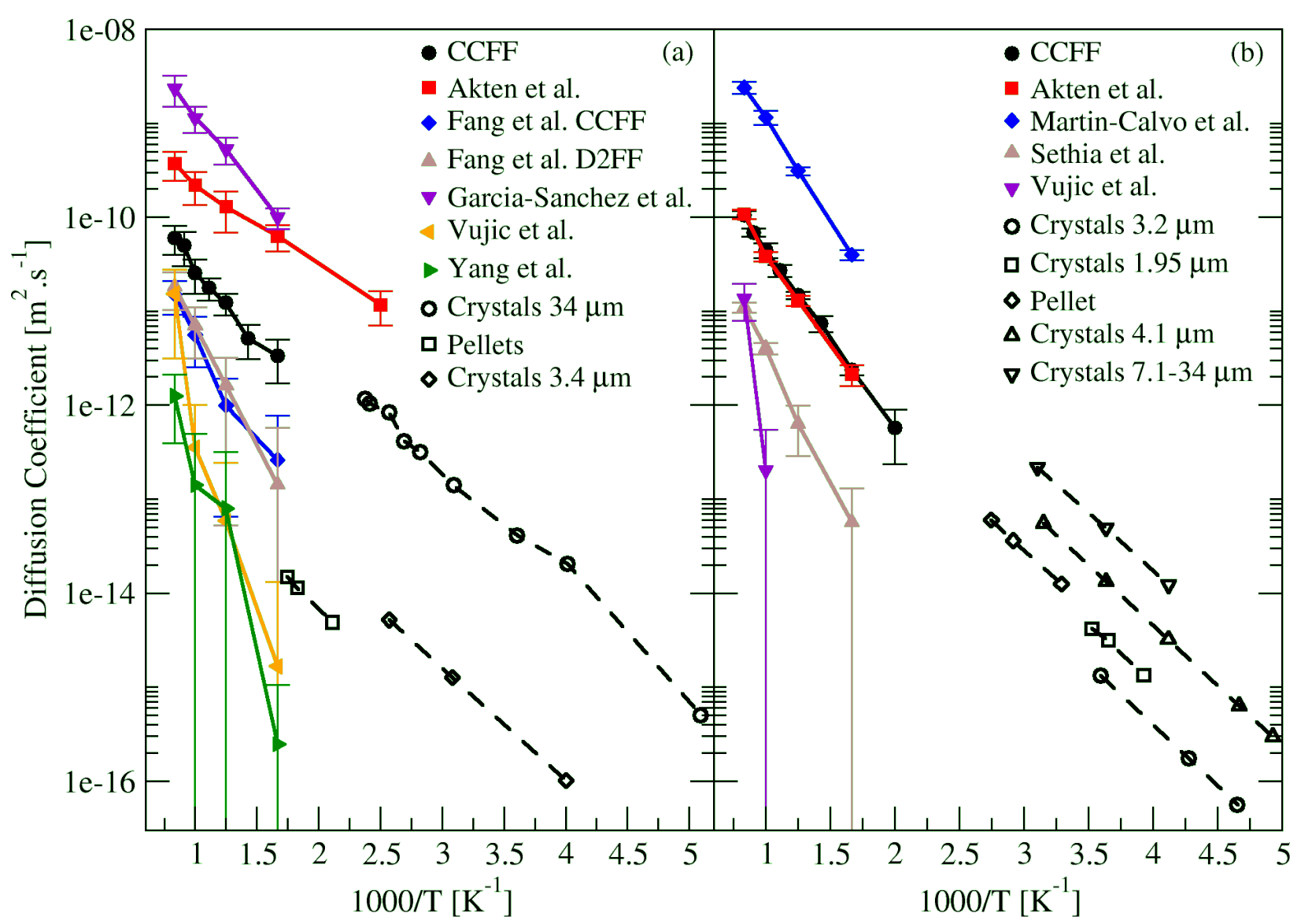

Figure S24. Temperature dependence of diffusivities of (a) $\mathrm{CO}_{2}$ and (b) $\mathrm{N}_{2}$ in $4 \mathrm{~A}$ zeolite with $\mathrm{Si} / \mathrm{Al}=1$ using CCFF and other FFs from the literature (filled symbols). Experimental data ${ }^{49-57}$ using different samples and techniques are taken from Kärger et al. ${ }^{58}$. 
Table S13. Activation energies (in $\mathrm{kJ} / \mathrm{mol}$ ) of $\mathrm{CO}_{2}, \mathrm{~N}_{2}$, and $\mathrm{CH}_{4}$ in $\mathrm{K}-\mathrm{LTA}$ structures in function of $\mathrm{Si} / \mathrm{Al}$ ratio.

\begin{tabular}{llll}
\hline Molecule & \multicolumn{3}{c}{$\mathrm{Si} / \mathrm{Al}$} \\
\cline { 2 - 4 } & 2 & 3 & 5 \\
\hline $\mathrm{CO}_{2}$ & 35 & 27 & 15 \\
\hline $\mathrm{N}_{2}$ & 66 & 28 & 7 \\
\hline $\mathrm{CH}_{4}$ & 59 & 47 & 11 \\
\hline
\end{tabular}

Table S14. The occupancy of 8-ring and 6-ring sites in K-LTA in function of Si/Al ratio.

\begin{tabular}{ccccc}
\hline Site & \multicolumn{4}{c}{$\mathrm{Si} / \mathrm{Al}$} \\
\cline { 2 - 5 } & 1 & 2 & 3 & 5 \\
\hline 8-ring & 1 & 0.96 & 0.92 & 0.67 \\
\hline 6-ring & 1 & 0.64 & 0.41 & 0.25 \\
\hline
\end{tabular}




\section{S5. Sample LAMMPS Input File}

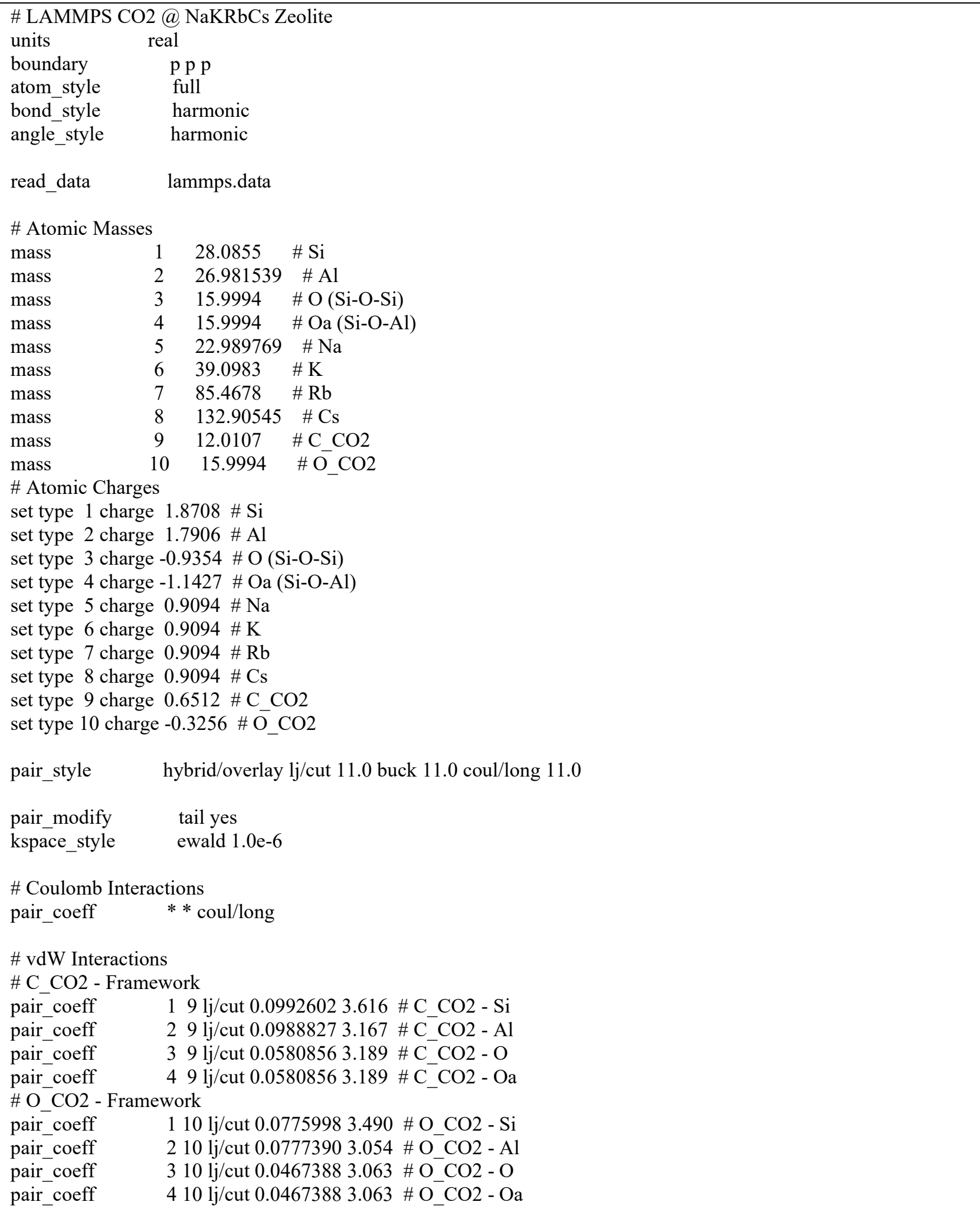




\begin{tabular}{|c|c|}
\hline \multicolumn{2}{|c|}{ \# C_CO2 - Cations } \\
\hline pair_coeff & $59 \mathrm{lj} /$ cut 0.20507802 .659 \# C_CO2 - Na \\
\hline pair_coeff & $69 \mathrm{lj} /$ cut 0.34597002 .993 \# C_CO2 - K \\
\hline pair_coeff & $79 \mathrm{lj} /$ cut 0.20011003 .306 \# C_CO2 - Rb \\
\hline pair_coeff & $89 \mathrm{lj} /$ cut 0.13848703 .578 \# C-CO2 - Cs \\
\hline \multicolumn{2}{|c|}{ \# O_CO2 - Cations } \\
\hline pair_coeff & $510 \mathrm{lj} /$ cut 0.16809702 .547 \# O_CO2 - Na \\
\hline pair_coeff & $610 \mathrm{lj} /$ cut 0.27522602 .881 \# O_CO2 - K \\
\hline pair_coeff & $710 \mathrm{lj} /$ cut 0.15744503 .188 \# O_CO2 - Rb \\
\hline pair_coeff & $810 \mathrm{lj} /$ cut 0.10766603 .457 \# O_CO2 - Cs \\
\hline \multicolumn{2}{|c|}{ \# Framework - Cations } \\
\hline pair coeff & 35 buck $110905.000 .2509411821 .66 \# \mathrm{Na}-\mathrm{O}$ \\
\hline pair_coeff & 36 buck 138448.000 .2877705200 .48 \# K - O \\
\hline pair_coeff & 37 buck 82468.500 .3097894413 .55 \# Rb - O \\
\hline pair_coeff & 38 buck 87833.900 .35161712914 .80 \# Cs - O \\
\hline pair coeff & 45 buck $110905.000 .2509411821 .66 \mathrm{\#} \mathrm{Na}-\mathrm{Oa}$ \\
\hline pair_coeff & 46 buck 138448.000 .2877705200 .48 \# K - Oa \\
\hline pair_coeff & 47 buck 82468.500 .3097894413 .55 \# Rb - Oa \\
\hline pair_coeff & 48 buck 87833.900 .35161712914 .80 \# Cs - Oa \\
\hline \multicolumn{2}{|l|}{ \# $\mathrm{CO} 2-\mathrm{CO} 2$} \\
\hline pair_coeff & $99 \mathrm{lj} /$ cut 0.055897712 .757 \\
\hline pair_coeff & $910 \mathrm{lj} /$ cut 0.094566482 .895 \\
\hline pair_coeff & $1010 \mathrm{lj} /$ cut 0.159982803 .033 \\
\hline \multicolumn{2}{|l|}{ \# Bond CO2 } \\
\hline \multicolumn{2}{|c|}{ bond_coeff 10.01 .1490} \\
\hline \multirow{2}{*}{\multicolumn{2}{|c|}{$\begin{array}{l}\text { \# Angle CO2 } \\
\text { angle_coeff } 1147.70554495180 .0\end{array}$}} \\
\hline & \\
\hline neighbor & $2.0 \mathrm{bin}$ \\
\hline neigh_modify & every 5 delay 0 check yes \\
\hline run_style & verlet \\
\hline timēestep & 1.0 \\
\hline \multicolumn{2}{|c|}{ \# group Cations $+\mathrm{CO} 2$} \\
\hline \multirow{2}{*}{\multicolumn{2}{|c|}{ \# group $\mathrm{CO} 2$}} \\
\hline & $\begin{array}{l}\text { \# group CO2 } \\
\text { group }\end{array}$ \\
\hline & \\
\hline thermo & 100 \\
\hline $\log$ & thermo.log \\
\hline \multicolumn{2}{|c|}{ thermo_style custom step etotal enthalpy vol press temp cella cellb cellc cellalpha cellbeta cellgamma } \\
\hline velocity & all create 300.0918172 rot yes mom yes dist gaussian \\
\hline dump & 1 all xyz 100 HISTORY.xyz \\
\hline dump_modify & 1 element $\mathrm{Si}$ Al O O Na K Rb Cs C O \\
\hline \multicolumn{2}{|c|}{ \# SHAKE applied to $\mathrm{C}=\mathrm{O}$ bond of $\mathrm{CO} 2$} \\
\hline \\
\hline \multirow{2}{*}{\multicolumn{2}{|c|}{$\begin{array}{l}\text { \# NVT MD Cations+CO2 Only - Framework is rigid } \\
\text { fix } \quad 2 \text { mobile nvt temp } \$ \mathrm{t} \$ \mathrm{t} 100\end{array}$}} \\
\hline & \\
\hline run & 10000 \\
\hline
\end{tabular}




\section{References}

1. Findley, J. M.; Boulfelfel, S. E.; Fang, H.; Muraro, G.; Ravikovitch, P. I.; Sholl, D. S., A Transferable Force Field for Predicting Adsorption and Diffusion of Hydrocarbons and Small Molecules in Silica Zeolites with Coupled-Cluster Accuracy. The Journal of Physical Chemistry C 2021, 125 (15), 8418-8429.

2. Lemmon, E. W.; McLinden, M. O.; Friend, D. G., Thermophysical properties of fluid systems. In NIST Chemistry WebBook, NIST Standard Reference Database Number 69, Linstrom, P. J.; Mallard, W. G., Eds. National Institute of Standards and Technology: Gaithersburg, MD, 20899, 1998.

3. Harris, J. G.; Yung, K. H., Carbon dioxide's liquid-vapor coexistence curve and critical properties as predicted by a simple molecular model. The Journal of Physical Chemistry 1995, 99 (31), 12021-12024.

4. Makrodimitris, K.; Papadopoulos, G. K.; Theodorou, D. N., Prediction of permeation properties of $\mathrm{CO}_{2}$ and $\mathrm{N}_{2}$ through silicalite via molecular simulations. The Journal of Physical Chemistry B 2001, 105 (4), 777-788.

5. Murthy, C.; Singer, K.; Klein, M.; McDonald, I., Pairwise additive effective potentials for nitrogen. Molecular Physics 1980, 41 (6), 1387-1399.

6. Zhang, L.; Siepmann, J. I., Direct calculation of Henry's law constants from Gibbs ensemble Monte Carlo simulations: nitrogen, oxygen, carbon dioxide and methane in ethanol. Theoretical Chemistry Accounts 2006, 115 (5), 391-397.

7. Jorgensen, W. L.; Maxwell, D. S.; Tirado-Rives, J., Development and testing of the OPLS all-atom force field on conformational energetics and properties of organic liquids. Journal of the American Chemical Society 1996, 118 (45), 11225-11236.

8. Pluth, J. J.; Smith, J. V., Accurate redetermination of crystal structure of dehydrated zeolite A. Absence of near zero coordination of sodium. Refinement of silicon, aluminumordered superstructure. Journal of the American Chemical Society 1980, 102 (14), 4704-4708.

9. Jirak, Z.; Vratislav, S.; Bosáček, V., A neutron diffraction study of H, Na-Y zeolites. Journal of Physics and Chemistry of Solids 1980, 41 (10), 1089-1095.

10. Ikeda, T.; Kodaira, T.; Oh, T.; Nisawa, A., K+ ion distribution in zeolite ZK-4's with various $\mathrm{Si} / \mathrm{Al}$ ratios and the contribution of $\mathrm{K}+$ ions to $\mathrm{K}$ cluster formation. Microporous and mesoporous materials 2003, 57 (3), 249-261.

11. Mortier, W.; Bosmans, H.; Uytterhoeven, J., Location of univalent cations in synthetic zeolites of the $\mathrm{Y}$ and $\mathrm{X}$ type with varying silicon to aluminum ratio. II. Dehydrated potassium exchanged forms. The Journal of Physical Chemistry 1972, 76 (5), 650-656.

12. Van Dun, J.; Mortier, W.; Uytterhoeven, J., Influence of the temperature and the adsorption of benzene on the location of K, Ca and $\mathrm{Sr}$ in Y-type zeolites. Zeolites 1985, 5 (4), 257-260.

13. Lozinska, M. M.; Mowat, J. P.; Wright, P. A.; Thompson, S. P.; Jorda, J. L.; Palomino, M.; Valencia, S.; Rey, F., Cation gating and relocation during the highly selective "trapdoor" adsorption of $\mathrm{CO}_{2}$ on univalent cation forms of zeolite RHO. Chemistry of Materials 2014, 26 (6), 2052-2061.

14. Hedin, N.; DeMartin, G. J.; Roth, W. J.; Strohmaier, K. G.; Reyes, S. C., PFG NMR self-diffusion of small hydrocarbons in high silica DDR, CHA and LTA structures. Microporous and Mesoporous Materials 2008, 109 (1-3), 327-334. 
15. Maghsoudi, H.; Soltanieh, M.; Bozorgzadeh, H.; Mohamadalizadeh, A., Adsorption isotherms and ideal selectivities of hydrogen sulfide and carbon dioxide over methane for the SiCHA zeolite: comparison of carbon dioxide and methane adsorption with the all-silica DD3R zeolite. Adsorption 2013, 19 (5), 1045-1053.

16. Pham, T. D.; Lobo, R. F., Adsorption equilibria of $\mathrm{CO}_{2}$ and small hydrocarbons in AEI-, CHA-, STT-, and RRO-type siliceous zeolites. Microporous and Mesoporous Materials 2016, 236, 100-108.

17. Palomino, M.; Corma, A.; Rey, F.; Valencia, S., New Insights on $\mathrm{CO}_{2}-\mathrm{Methane}$ separation using LTA zeolites with different $\mathrm{Si} / \mathrm{Al}$ ratios and a first comparison with MOFs. Langmuir 2010, 26 (3), 1910-1917.

18. Epiepang, F. E.; Li, J.; Liu, Y.; Yang, R. T., Low-pressure performance evaluation of $\mathrm{CO}_{2}, \mathrm{H}_{2} \mathrm{O}$ and $\mathrm{CH}_{4}$ on Li-LSX as a superior adsorbent for air prepurification. Chemical Engineering Science 2016, 147, 100-108.

19. Ridha, F. N.; Webley, P. A., Anomalous Henry's law behavior of nitrogen and carbon dioxide adsorption on alkali-exchanged chabazite zeolites. Separation and purification technology 2009, 67 (3), 336-343.

20. Pham, T. D.; Hudson, M. R.; Brown, C. M.; Lobo, R. F., On the Structure - Property Relationships of Cation - Exchanged ZK - 5 Zeolites for $\mathrm{CO}_{2}$ Adsorption. ChemSusChem 2017, 10 (5), 946-957.

21. Fang, H.; Kamakoti, P.; Ravikovitch, P. I.; Aronson, M.; Paur, C.; Sholl, D. S., First principles derived, transferable force fields for $\mathrm{CO}_{2}$ adsorption in Na-exchanged cationic zeolites. Physical Chemistry Chemical Physics 2013, 15 (31), 12882-12894.

22. Dunne, J.; Rao, M.; Sircar, S.; Gorte, R.; Myers, A., Calorimetric heats of adsorption and adsorption isotherms. 2. $\mathrm{O}_{2}, \mathrm{~N}_{2}, \mathrm{Ar}, \mathrm{CO}_{2}, \mathrm{CH}_{4}, \mathrm{C}_{2} \mathrm{H}_{6}$, and $\mathrm{SF}_{6}$ on NaX, H-ZSM-5, and NaZSM-5 zeolites. Langmuir 1996, 12 (24), 5896-5904.

23. Walton, K. S.; Abney, M. B.; LeVan, M. D., $\mathrm{CO}_{2}$ adsorption in $\mathrm{Y}$ and $\mathrm{X}$ zeolites modified by alkali metal cation exchange. Microporous and Mesoporous Materials 2006, 91 (13), 78-84.

24. Khvoshchev, S. S.; Zverev, A. V., Calorimetric study of $\mathrm{NH}_{3}$ and $\mathrm{CO}_{2}$ adsorption on synthetic faujasites with $\mathrm{Ca}^{2+}, \mathrm{Mg}^{2+}$, and $\mathrm{La}^{3+}$ cations. Journal of colloid and interface science 1991, 144 (2), 571-578.

25. Pirngruber, G.; Raybaud, P.; Belmabkhout, Y.; Čejka, J.; Zukal, A., The role of the extra-framework cations in the adsorption of $\mathrm{CO}_{2}$ on faujasite Y. Physical Chemistry Chemical Physics 2010, 12 (41), 13534-13546.

26. Remy, T.; Peter, S. A.; Van Tendeloo, L.; Van der Perre, S.; Lorgouilloux, Y.; Kirschhock, C. E.; Baron, G. V.; Denayer, J. F., Adsorption and separation of $\mathrm{CO}_{2}$ on KFI zeolites: effect of cation type and $\mathrm{Si} / \mathrm{Al}$ ratio on equilibrium and kinetic properties. Langmuir 2013, 29 (16), 4998-5012.

27. Pham, T. D.; Liu, Q.; Lobo, R. F., Carbon dioxide and nitrogen adsorption on cationexchanged SSZ-13 zeolites. Langmuir 2013, 29 (2), 832-839.

28. Yang, X.; Epiepang, F. E.; Liu, Y.; Yang, R. T., Heats of adsorption on mixed-cation LiNa-LSX: Estimating SIII site occupancy by Li. Chemical Engineering Science 2018, 178, 194198.

29. Findley, J. M.; Ravikovitch, P. I.; Sholl, D. S., The effect of aluminum short-range ordering on carbon dioxide adsorption in zeolites. The Journal of Physical Chemistry C 2018, 122 (23), 12332-12340. 
30. Shang, J.; Li, G.; Singh, R.; Gu, Q.; Nairn, K. M.; Bastow, T. J.; Medhekar, N.; Doherty, C. M.; Hill, A. J.; Liu, J. Z., Discriminative separation of gases by a "molecular trapdoor" mechanism in chabazite zeolites. Journal of the American Chemical Society 2012, 134 (46), 19246-19253.

31. Akten, E. D.; Siriwardane, R.; Sholl, D. S., Monte Carlo simulation of single- and binary-component adsorption of $\mathrm{CO}_{2}, \mathrm{~N}_{2}$, and $\mathrm{H}_{2}$ in zeolite Na-4A. Energ Fuel 2003, 17 (4), 977-983.

32. Vujic, B.; Lyubartsev, A. P., Transferable force-field for modelling of $\mathrm{CO}_{2}, \mathrm{~N}_{2}, \mathrm{O}_{2}$ and Ar in all silica and $\mathrm{Na}+$ exchanged zeolites. Model Simul Mater Sc 2016, 24 (4).

33. Newsome, D.; Gunawan, S.; Baron, G.; Denayer, J.; Coppens, M. O., Adsorption of $\mathrm{CO}_{2}$ and $\mathrm{N}_{2}$ in Na-ZSM-5: effects of $\mathrm{Na}+$ and $\mathrm{Al}$ content studied by Grand Canonical Monte Carlo simulations and experiments. Adsorption-Journal of the International Adsorption Society 2014, 20 (1), 157-171.

34. Martin-Calvo, A.; Gutierrez-Sevillano, J. J.; Parra, J. B.; Ania, C. O.; Calero, S., Transferable force fields for adsorption of small gases in zeolites. Physical Chemistry Chemical Physics 2015, 17 (37), 24048-24055.

35. Maurin, G.; Llewellyn, P. L.; Bell, R. G., Adsorption mechanism of carbon dioxide in faujasites: Grand canonical Monte Carlo simulations and microcalorhnetry measurements. $J$ Phys Chem B 2005, 109 (33), 16084-16091.

36. Sethia, G.; Pillai, R. S.; Dangi, G. P.; Somani, R. S.; Bajaj, H. C.; Jasra, R. V., Sorption of Methane, Nitrogen, Oxygen, and Argon in ZSM-5 with different $\mathrm{SiO}_{2} / \mathrm{Al}_{2} \mathrm{O}_{3} \mathrm{Ratios}$ Grand Canonical Monte Carlo Simulation and Volumetric Measurements. Industrial \& Engineering Chemistry Research 2010, 49 (5), 2353-2362.

37. Strzempek, M.; Tarach, K.; Gora-Marek, K.; Rey, F.; Palomino, M.; Valencia, S.; Piskorz, W., Multiscale exploration of hydrocarbon adsorption and hopping through ZSM-5 channels - from Monte Carlo modelling to experiment. Physical Chemistry Chemical Physics 2021, 23 (4), 2981-2990.

38. Fang, H. J.; Kamakoti, P.; Ravikovitch, P. I.; Aronson, M.; Paur, C.; Sholl, D. S., First principles derived, transferable force fields for $\mathrm{CO}_{2}$ adsorption in Na-exchanged cationic zeolites. Physical Chemistry Chemical Physics 2013, 15 (31), 12882-12894.

39. Garcia-Sanchez, A.; Ania, C. O.; Parra, J. B.; Dubbeldam, D.; Vlugt, T. J. H.; Krishna, R.; Calero, S., Transferable Force Field for Carbon Dioxide Adsorption in Zeolites. J Phys Chem C 2009, 113 (20), 8814-8820.

40. Jaramillo, E.; Chandross, M., Adsorption of small molecules in LTA zeolites. 1. $\mathrm{NH}_{3}$, $\mathrm{CO}_{2}$, and $\mathrm{H}_{2} \mathrm{O}$ in zeolite 4A. J Phys Chem B 2004, 108 (52), 20155-20159.

41. Calero, S.; Dubbeldam, D.; Krishna, R.; Smit, B.; Vlugt, T. J. H.; Denayer, J. F. M.; Martens, J. A.; Maesen, T. L. M., Understanding the role of sodium during adsorption: A force field for alkanes in sodium-exchanged faujasites. Journal of the American Chemical Society 2004, 126 (36), 11377-11386.

42. Yang, K. Z.; Wu, J. Y.; Li, C. Y.; Xiang, Y.; Yang, G., Efficient Method To Obtain the Force Field for $\mathrm{CO}_{2}$ Adsorption on Zeolite 13X: Understanding the Host-Guest Interaction Mechanisms of Low-Pressure Adsorption. J Phys Chem C 2020, 124 (1), 544-556.

43. Pillai, R. S.; Sethia, G.; Jasra, R. V., Sorption of $\mathrm{CO}, \mathrm{CH}_{4}$, and $\mathrm{N}_{2}$ in Alkali Metal Ion Exchanged Zeolite-X: Grand Canonical Monte Carlo Simulation and Volumetric Measurements. Industrial \& Engineering Chemistry Research 2010, 49 (12), 5816-5825. 
44. Karger, J.; Pfeifer, H.; Rauscher, M.; Walter, A., Self-Diffusion of N-Paraffins in NaX Zeolite. J Chem Soc Farad T 1 1980, 76, 717-737.

45. Karger, J.; Pfeifer, H.; Stallmach, F.; Feoktistova, N. N.; Zhdanov, S. P., Xe-129 and C13 PFG NMR-Study of the Intracrystalline Self-Diffusion of $\mathrm{Xe}, \mathrm{CO}_{2}$, and $\mathrm{CO}$. Zeolites 1993, 13 (1), 50-55.

46. Bar, N. K.; McDaniel, P. L.; Coe, C. G.; Seiffert, G.; Karger, J., Measurement of intracrystalline diffusion of nitrogen in zeolites $\mathrm{NaX}$ and $\mathrm{NaCaA}$ using pulsed field gradient N.M.R. Zeolites 1997, 18 (1), 71-74.

47. Caro, J.; Bulow, M.; Schirmer, W.; Karger, J.; Heink, W.; Pfeifer, H.; Zdanov, S. P., Microdynamics of Methane, Ethane and Propane in ZSM-5-Type Zeolites. J Chem Soc Farad T 1 1985, 81, 2541-2550.

48. Deroche, I.; Maurin, G.; Borah, B. J.; Yashonath, S.; Jobic, H., Diffusion of Pure $\mathrm{CH}_{4}$ and Its Binary Mixture with $\mathrm{CO}_{2}$ in Faujasite NaY: A Combination of Neutron Scattering Experiments and Molecular Dynamics Simulations. J Phys Chem C 2010, 114 (11), 5027-5034.

49. Ruthven, D. M., Diffusion in type A zeolites: New insights from old data. Microporous and Mesoporous Materials 2012, 162, 69-79.

50. Yucel, H.; Ruthven, D. M., Diffusion of $\mathrm{CO}_{2}$ in 4A and 5A Zeolite Crystals. J Colloid Interf Sci 1980, 74 (1), 186-195.

51. Yucel, H.; Ruthven, D. M., Diffusion in 4A-Zeolite - Study of the Effect of Crystal Size. $J$ Chem Soc Farad T 1 1980, 76, 60-70.

52. Haq, N.; Ruthven, D. M., Chromatographic Study of Sorption and Diffusion in 4A Zeolite. Journal of Colloid and Interface Science 1986, 112 (1), 154-163.

53. Ruthven, D. M., Short communication: Diffusion of simple molecules in 4A zeolite. Adsorption-Journal of the International Adsorption Society 2001, 7 (4), 301-304.

54. Cao, D. V.; Mohr, R. J.; Rao, M. B.; Sircar, S., Self-diffusivities of $\mathrm{N}_{2}, \mathrm{CH}_{4}$, and $\mathrm{Kr}$ on 4A zeolite pellets by isotope exchange technique. J Phys Chem B 2000, 104 (45), 10498-10501.

55. Eagan, J. D.; Anderson, R. B., Kinetics and Equilibrium of Adsorption on 4A Zeolite. Journal of Colloid and Interface Science 1975, 50 (3), 419-433.

56. Ruthven, D. M.; Derrah, R. I., Diffusion of Monatomic and Diatomic Gases in 4AZeolites and 5A-Zeolites. J Chem Soc Farad T 1 1975, 71, 2031-2044.

57. Ruthven, D. M.; Kumar, R., Chromatographic Study of the Diffusion of $\mathrm{N}_{2}, \mathrm{CH}_{4}$ and Binary $\mathrm{CH}_{4}-\mathrm{N}_{2}$ Mixtures in 4A Molecular-Sieve. Can J Chem Eng 1979, 57 (3), 342-348.

58. Kärger, J.; Ruthven, D. M.; Theodorou, D. N.; Kärger, J.; Krger, J.; Krger, J., Diffusion in Nanoporous Materials. John Wiley \& Sons, Incorporated: Weinheim, GERMANY, 2012. 